\title{
The Implementation of Industrial Byproduct in Malaysian Peat Improvement: A Sustainable Soil Stabilization Approach
}

\author{
Afnan Ahmad ${ }^{1, *} \mathbb{0}$, Muslich Hartadi Sutanto ${ }^{1}$, Niraku Rosmawati binti Ahmad ${ }^{1}$, Mastura Bujang ${ }^{2}$ \\ and Mazizah Ezdiani Mohamad ${ }^{2}$ \\ 1 Department of Civil \& Environmental Engineering, Universiti Teknologi PETRONAS, \\ Seri Iskandar 32610, Malaysia; muslich.sutanto@utp.edu.my (M.H.S.); niraku.ahmad@utp.edu.my (N.R.b.A.) \\ 2 Civil Engineering Programme, School of Engineering and Technology, University Technology Sarawak, \\ Sarawak 96000, Malaysia; mastura.bujang@ucts.edu.my (M.B.); mazizah@ucts.edu.my (M.E.M.) \\ * Correspondence: afnanahmad905@gmail.com
}

Citation: Ahmad, A.; Sutanto, M.H.; Ahmad, N.R.b.; Bujang, M.;

Mohamad, M.E. The Implementation of Industrial Byproduct in Malaysian Peat Improvement: A Sustainable Soil Stabilization Approach. Materials 2021, 14, 7315. https://doi.org/ $10.3390 /$ ma14237315

Academic Editor: Neven Ukrainczyk

Received: 28 August 2021

Accepted: 29 September 2021

Published: 29 November 2021

Publisher's Note: MDPI stays neutral with regard to jurisdictional claims in published maps and institutional affiliations.

Copyright: (c) 2021 by the authors. Licensee MDPI, Basel, Switzerland. This article is an open access article distributed under the terms and conditions of the Creative Commons Attribution (CC BY) license (https:// creativecommons.org/licenses/by/ $4.0 /)$.
Abstract: Peat is a well-known problematic soil associated with poor engineering properties. Its replacement with an expensive competent foundation material is practiced for road embankment construction which is costly and causes greenhouse gas emissions. Therefore, this paper investigated the effectiveness of a byproduct from a metal industry (silica fume) to stabilize peat along with ordinary Portland cement (OPC) through a series of experimental tests. After peat-indexed characterization, a number of standard compaction and mechanical tests were performed on the stabilized and parent peat. For this purpose, nine designated mixes were prepared possessing various combinations of silica fume (SF) and 10-20\% OPC. Unconfined compressive strength (UCS) and California Bearing Ratio (CBR) tests were carried out after 7, 14, and 28 days of curing to assess strength enhancement and binder effectiveness, and the microstructural evolution induced by the binders was examined with scanning electron microscopy (SEM). The analysis revealed a substantial improvement in mechanical properties with the incorporation of SF and OPC, ultimately meeting the minimum strength requirement for highway construction (i.e., $345 \mathrm{kPa}$ ). A peak UCS of $1063.94 \mathrm{kPa}$ was recorded at $20 \% \mathrm{SF}$, and an unsoaked CBR value of 42.95 was observed using $15 \% \mathrm{SF}$ and $15 \%$ OPC after 28 days of curing. Furthermore, the increasing percentage of hydraulic binders exhibited brittle, collapsible failure, while the microstructural study revealed the formation of a dense matrix with a refined pore structure in the treated peat. Finally, a significant statistical analysis was carried out by correlating the test parameters. In this way, rather than stockpiling and dumping, an industrial byproduct was implemented in peat stabilization in an eco-friendly manner.

Keywords: peat; sustainable soil stabilization; eco-friendly; reuse of industrial byproducts; unconfined compressive strength; California Bearing Capacity; scanning electron microscope

\section{Introduction}

Histosol, moss, bogs, fen, and mires are widely classified as peat soil that originates from the anaerobic decaying of plants and animals. Peat soil is considered the most undesirable base material for any sort of construction activity [1]. The poor engineering properties associated with peatland, i.e., high water content and high void ratio, result in low shear strength and compressible behavior, making it unable to bear infrastructure loads. Unluckily, peatland comprises 3\% of the world's land, with Canada and the former USSR being the major contributors; $8 \%$ of Malaysia, a tropical country, comprises peatland [2]. However, the rapid growth of Malaysia in Southeast Asia has demanded land acquisition for development projects such as highway construction, housing societies, and industrialization. Thus, the stabilization of peat soil is necessary to attain desirable load-bearing capacities and utilize unserviceable peatland for developing schemes.

Among various soil stabilization techniques, sustainable chemical stabilization gaining interest around the globe [3]. Several binders, including traditional and non-traditional 
additives, are currently used to strengthen peat [1,2]. However, the implementation of secondary waste materials is highly encouraged to avoid the pressing issues of its disposal [4]. Various raw materials, including scraped tires, demolished concrete waste, silica fume, blast furnace slag, gypsum, oil shale, municipal solid waste, fly ash, and palm oil fuel ashes, have been adopted for the stabilization of peat [2,4]. The implementation of these additives causes physical and chemical changes in peat soil in favor of engineering applications. For instance, Mahmood et al. [5] utilized palm oil fuel ash (POFA) in Malaysian peat at $5 \%, 10 \%, 15 \%$, and $20 \%$; an approximate 4 -fold increase in the maximum dry density and 31-40-fold-higher CBR values were reported.

Silica fume (SF) is a byproduct derived from the smelting process of silicon, and an alloy containing silicon in an electric arc furnace possesses an extremely fine spherical shape (1/100th of ordinary Portland cement), thus causing health and environmental issues upon dumping and mixing in an open atmosphere. However, its highly amorphous nature with enriched silicon dioxide makes it substantially pozzolanic [6]. The silicon dioxide reacts with the calcium hydroxide in the presence of water to produce calcium silicate hydrate gel, which is responsible for the strength improvement of problematic soil [7]. Therefore, SF has been extensively adopted in the stabilization of peat soil [7-9]. For instance, Kalantari et al. [7] utilized SF in the presence of cement to assess the mechanical and compressibility characteristics of peat. The same authors further conducted a comparative study of cement $(5-50 \%)$ and SF (5-10\%) via unconfined compressive strength (UCS) and California Bearing Capacity (CBR) tests in peat stabilization [8]. The effectiveness of adopting SF in the presence of ordinary Portland cement (OPC) for the stabilization of peat has been previously highlighted.

SF and OPC not only bring physical changes but also alter the chemical composition of soil. The micrographs of untreated and cement-, silica-sand-, and kaolin-stabilized peat reported by Wong et al. [10] revealed a clear transformation from loosely packed peat to a compact solid matrix. Moreover, Rikmann et al. [9] performed microstructural testing (XRD, $\mathrm{XRF}$, and FTIR) of the utilization of cement and shale ash in peat stabilization; their results supported the application of pozzolanic additives such as silica fume, $\mathrm{pH}$-modified alkali, and water glass without the addition of ordinary Portland cement for the stabilization of peat soil. In summation, previous findings have shown that both silica fume and OPC are potential binders in peat stabilization.

The stabilization process of soil, especially in the case of peat, is a highly site-specific task because it depends on a number of factors, e.g., peat type, water content, and acidity, as reported by Hebib and Farrell [11]. Additionally, the concentration of humic and fulvic compounds in peat is a key factor that causes an inhibitory effect on the hardening of binder-soil mixtures. However, studies on Peninsular Malaysian peat stabilization via SF and OPC have been limited. The performance of SF and OPC in Peninsular Malaysian peat soil has been exclusively assessed through mechanical testing. Thus, an inclusive mechanical and microstructural assessment of Peninsular Malaysian peat utilizing SF and OPC for soil stabilization is needed to better predict the engineering behavior of the stabilized peat matrixes. Furthermore, comparative analyses of the binder's effectiveness in peat stabilization are lacking.

In the current research work, the chemical stabilization of Malaysian peat soil was carried out through a series of compaction and mechanical tests, and the morphological characteristics were investigated via scanning electron microscopy (SEM) to examine and compare the microstructural evolution of the parent and stabilized peat matrixes caused by SF and OPC. The mechanical assessment involved a UCS test followed by failure pattern examination and a CBR test in light of the highway construction criterion. Furthermore, strong statistical correlations were examined to investigate the effect of one parameter on the others. Overall, the effectiveness of silica fume with and without cement was assessed in the context of Peninsular Malaysian peat enhancement via mechanical and microstructural approaches. 


\section{Materials and Experimental Procedure}

\subsection{Peat Collection}

The peat soil utilized for the experimental investigations was collected from the Kampung Baru, Teluk Intan, Perak state of Peninsular Malaysia. The coordinates of the peat soil sampling were $4^{\circ} 00^{\prime} 16.1^{\prime \prime} \mathrm{N}, 101^{\circ} 11^{\prime} 11.0^{\prime \prime} \mathrm{E}$, and peat sampling was carried out at 5 feet $(1.52 \mathrm{~m})$ of depth. The peat's chemical composition by percentage weight is illustrated in Table 1.

Table 1. Chemical compositions (weight percentages) of peat, $\mathrm{SF}$, and OPC revealed by XRF analysis.

\begin{tabular}{cccc}
\hline Oxides $(\%$ Weight $)$ & Peat & Silica Fume & OPC \\
\hline $\mathrm{CO}_{2}$ & 90.12 & - & - \\
$\mathrm{Al}_{2} \mathrm{O}_{3}$ & 0.746 & 0.876 & 2.68 \\
$\mathrm{SiO}_{2}$ & 6.64 & 91.0 & 12.3 \\
$\mathrm{CaO}$ & 0.355 & 1.20 & 75.5 \\
$\mathrm{Fe}_{2} \mathrm{O}_{3}$ & 0.673 & 3.39 & 2.86 \\
$\mathrm{~K}_{2} \mathrm{O}$ & 0.045 & 1.42 & 0.479 \\
$\mathrm{TiO}_{2}$ & 0.020 & 0.013 & 0.231 \\
$\mathrm{SO}_{3}$ & 0.942 & 0.352 & 1.32 \\
$\mathrm{MgO}$ & 0.142 & 0.409 & 1.80 \\
$\mathrm{P}_{2}$ & 0.030 & - & - \\
$\mathrm{ZrO}$ & - & 0.075 & 0.217 \\
$\mathrm{MoO}_{3}$ & 0.24 & 0.052 & 1.29 \\
$\mathrm{MnO}$ & - & 0.205 & 0.411 \\
$\mathrm{ZnO}$ & 0.032 & 0.0292 & 0.0275 \\
Total weight $(\%)$ & 99.98 & 99.02 & 99.10
\end{tabular}

\subsection{Silica Fume and OPC (Binders)}

The silica fume, obtained from OM Materials (Sarawak) Sdn Bhd as a byproduct, was used as a potential binder in the Peninsular Malaysian peat stabilization. Silica fume is an industrial waste obtained as a secondary material from silicon and ferroalloy production. Moreover, it has a spherical shape with a diameter of approximately $150 \mathrm{~nm}$ (100 times smaller than cement granules). Additionally, it has a high pozzolanic potential and is widely used in high-performance concrete. The results of XRF analyses (chemical composition) of SF and OPC by percentage weight are shown in Table 1, and Table 2 illustrates the physical and chemical properties of the silica fume. Commonly available grade 53 OPC was utilized as an additional additive.

Table 2. Physical and chemical properties of silica fume.

\begin{tabular}{cc}
\hline Properties & Value/Description \\
\hline Appearance & Ultrafine amorphous powder \\
Color & Gray, off-white \\
Odor & Odorless \\
$\mathrm{pH} @ 20^{\circ} \mathrm{C}$ & $6.0-9.0$ \\
Solubility (water) & Insoluble $/$ slightly soluble \\
Solubility (organic solvents) & Insoluble $/$ slightly soluble \\
Boiling point & No information \\
Melting point & $1550-1700^{\circ} \mathrm{C}$ \\
Bulk density & $150-700 \mathrm{~kg} / \mathrm{m}^{3}$ \\
Specific gravity & $2100-2300 \mathrm{~kg} / \mathrm{m}^{3}$ \\
Particle Size & $0.4-0.5 \mu \mathrm{m}$ \\
\hline
\end{tabular}

\subsection{Mix Design}

Silica fume is a pozzolanic and industrial waste utilized for the stabilization of Peninsular Malaysian peat. The findings of Kalantari et al. [8] suggested that an effective SF content for peat with its natural moisture content is $20 \%$ by weight. In this study, three mixes 
containing SF in varying percentages $(10,15$, and $20 \%$ ) by weight of dry mass were taken into consideration [12], as shown in Table 3. Several trail mixes containing OPC and SF in varying amounts ranging from 5 to $15 \%$ were employed to stabilize Teluk Intan peat while keeping the cumulative binder amount below or equal to $20 \%$, as shown in Table 3 . For the sake of comparison, trial mixes of $15 \%$ OPC alone and in combination with $15 \% \mathrm{SF}$ were used.

Table 3. Summary of the mix design.

\begin{tabular}{cccc}
\hline Design Mixes & Peat & SF & OPC \\
\hline Peat & $100 \%$ & - & - \\
Peat and 10\% SF & $90 \%$ & $10 \%$ & - \\
Peat and 15\% SF & $85 \%$ & $15 \%$ & - \\
Peat and 20\% SF & $80 \%$ & $20 \%$ & $15 \%$ \\
Peat and 15\% OPC & $85 \%$ & - & $15 \%$ \\
Peat, 15\% SF, and 15\% OPC & $60 \%$ & $15 \%$ & $15 \%$ \\
Peat, 5\% SF, and 15\% OPC & $80 \%$ & $5 \%$ & $10 \%$ \\
Peat, 10\% SF, and 10\% OPC & $80 \%$ & $10 \%$ & $5 \%$ \\
Peat, 15\% SF, and 5\% OPC & $80 \%$ & $15 \%$ & 5 \\
\hline
\end{tabular}

\subsection{Specimen's Preparation and Curing}

Initially, the indexed properties of Teluk Intan peat were determined using disturbed soil collected from the sampling site. Subsequently, a series of standard compaction, UCS, and CBR tests were carried out on the treated and untreated peat. The compaction tests were performed on a peat sample passed through a No. 4 sieve utilizing a $101.6 \mathrm{~mm}$ (4 in) diameter mold. Similarly, the specimen preparation for UCS testing was carried out according to ASTM D2166/D2166M-16 [13]. As prescribed by ASTM guidelines, all specimens were molded to keep a height to diameter ratio of 2:1. Each UCS sample was prepared by tamping a mass of peat mixed with OMC into three layers in a cylindrical tube with a diameter equal to $35 \mathrm{~mm}$; each layer received 27 blows [10]. All molds were disclosed after one day, exposing the untreated peat to compressive testing while keeping the treated samples for 7, 14, and 28 days of curing. The curing technique prescribed by Kaniraj and Gayathri [14] was followed. All the stabilized UCS samples were carefully wrapped in airtight plastic bags and kept in a controlled environment for 7, 14, and 28 days of curing to avoid moisture loss and maintain temperature $\left(25^{\circ} \mathrm{C}\right)$. A similar curing procedure was adopted for CBR samples; following ASTM D 1883-16, using a mold with a diameter of $152.4 \mathrm{~mm}$ (6 in) and a height of $101.6 \mathrm{~mm}$ (4 in) [15].

\subsection{Experimental Testing Matrix}

The experimental procedure of peat stabilization was initiated with a basic properties' examination. These indexed properties play vital roles in peat characterization and may hinder the stabilization process. Table 4 illustrates the entire experimental matrix including standard compaction, UCS, and CBR. As illustrated in Table 4, a total of 9 (one parent and 8 treated peat) designated mixes were tested. Three trials of every test was conducted, and the averages of three tests are presented as the outcomes.

\subsubsection{Standard Compaction}

Standard compaction tests of the treated and untreated Teluk Intan peat were carried out according to ASTM D698-12 [16]; soil samples were subjected to about $600 \mathrm{kN}-\mathrm{m} / \mathrm{m}^{3}$ $\left(12,400 \mathrm{ft}-\mathrm{lbf} / \mathrm{ft}^{3}\right)$ over three layers, and maintained 25 blows per layer using a $24.5 \mathrm{~N}$ $(2.5 \mathrm{~kg})$ rammer dropped from a height of $305 \mathrm{~mm}$ (12 in). Cumulatively, 27 standard compaction tests were carried out on the 9 designated mixes by performing 3 trials on every mix. 
Table 4. Standard compaction and mechanical property testing matrix.

\begin{tabular}{|c|c|c|c|c|c|c|c|c|c|c|}
\hline \multirow{3}{*}{ Mixes } & \multirow{3}{*}{$\begin{array}{c}\text { Standard } \\
\text { Compaction }\end{array}$} & \multirow{2}{*}{\multicolumn{3}{|c|}{ UCS }} & \multicolumn{6}{|c|}{ CBR } \\
\hline & & & & & \multicolumn{3}{|c|}{ Soaked } & \multicolumn{3}{|c|}{ Unsoaked } \\
\hline & & $7 \mathrm{D}^{1}$ & $14 \mathrm{D}^{1}$ & $28 \mathrm{D}^{1}$ & $7 \mathrm{D}^{1}$ & $14 \mathrm{D}^{1}$ & $28 \mathrm{D}^{1}$ & $7 \mathrm{D}^{1}$ & $14 \mathrm{D}^{1}$ & $28 \mathrm{D}^{1}$ \\
\hline Peat & $\checkmark$ & - & - & - & - & - & - & - & - & - \\
\hline Peat and $10 \%$ SF & $\checkmark$ & $\checkmark$ & $\checkmark$ & $\checkmark$ & $\checkmark$ & $\checkmark$ & $\checkmark$ & $\checkmark$ & $\checkmark$ & $\checkmark$ \\
\hline Peat and $15 \%$ SF & $\checkmark$ & $\checkmark$ & $\checkmark$ & $\checkmark$ & $\checkmark$ & $\checkmark$ & $\checkmark$ & $\checkmark$ & $\checkmark$ & $\checkmark$ \\
\hline Peat and $20 \%$ SF & $\checkmark$ & $\checkmark$ & $\checkmark$ & $\checkmark$ & $\checkmark$ & $\checkmark$ & $\checkmark$ & $\checkmark$ & $\checkmark$ & $\checkmark$ \\
\hline Peat and $15 \%$ OPC & $\checkmark$ & $\checkmark$ & $\checkmark$ & $\checkmark$ & $\checkmark$ & $\checkmark$ & $\checkmark$ & $\checkmark$ & $\checkmark$ & $\checkmark$ \\
\hline Peat, $15 \%$ SF, and $15 \%$ OPC & $\checkmark$ & $\checkmark$ & $\checkmark$ & $\checkmark$ & $\checkmark$ & $\checkmark$ & $\checkmark$ & $\checkmark$ & $\checkmark$ & $\checkmark$ \\
\hline Peat, $5 \%$ SF, and $15 \%$ OPC & $\checkmark$ & $\checkmark$ & $\checkmark$ & $\checkmark$ & $\checkmark$ & $\checkmark$ & $\checkmark$ & $\checkmark$ & $\checkmark$ & $\checkmark$ \\
\hline Peat, $10 \% \mathrm{SF}$, and $10 \%$ OPC & $\checkmark$ & $\checkmark$ & $\checkmark$ & $\checkmark$ & $\checkmark$ & $\checkmark$ & $\checkmark$ & $\checkmark$ & $\checkmark$ & $\checkmark$ \\
\hline Peat, $15 \%$ SF, and $5 \%$ OPC & $\checkmark$ & $\checkmark$ & $\checkmark$ & $\checkmark$ & $\checkmark$ & $\checkmark$ & $\checkmark$ & $\checkmark$ & $\checkmark$ & $\checkmark$ \\
\hline
\end{tabular}

${ }^{1} \mathrm{D}$ denotes days of curing period; $\checkmark$ : Tests performed.

\subsubsection{Unconfined Compressive Strength (UCS)}

The UCS tests on the parent peat were conducted after one day of sampling, while the stabilized samples were exposed to the UCS test after curing periods of 7, 14, and 28 days. About 72 (24, 24, and 24) total stabilized UCS samples were tested after 7, 14, and 28 day curing periods, as described in Table 4. ASTM D2166/D2166M-16 [13] was followed for UCS testing.

\subsubsection{California Bearing Ratio (CBR)}

Like UCS, the CBR tests of the parent peat were carried out after one day of curing, while the stabilized, unsoaked specimens were exposed to load penetration after 7,14 , and 28 days of curing. The stabilized, soaked peat CBR samples were placed in the water bath for 4 days after curing before being subjected to load penetration. Collectively, 144 cumulatively ( 72 soaked and 72 unsoaked) stabilized CBR samples were tested after 7 , 14, and 28 days of curing, as illustrated in Table 4. ASTM D 1883-16 [15] was followed for the CBR testing procedure.

\subsubsection{Scanning Electron Microscopy (SEM)}

SEM was used to assess and compare the morphology of the treated and parent Teluk Intan peat. The SEM machine (Zeiss EVO LS 15, Seri Iskandar, Perak, Malaysia) available in the Universiti Teknologi Petronas was utilized for all micrographs. The untreated peat and stabilized peat cured for 28 days were SEM-imaged at magnifications of $1000 \times-10 \mathrm{k} \times$.

\section{Results and Discussion}

\subsection{Peat Indexed Properties}

Peat soil is predominantly composed of organic and mineral components. The first component is carbonaceous in origin and combustible in nature, and the mineral constituents form ash after burning due to their incombustible nature. Both these constituents play vital roles in classification and influence peat behavior [17]. The experimental findings indicated that Teluk Intan peat contains $80.86 \%$ of organic content and $19.13 \%$ of ash content, as presented in Table 5 . Thus, it is clear that the collected sample possessed more than $75 \%$ of organic matter, so they could be termed "peat" according to ASTM D $4427-13[18,19]$. Additionally, the peat samples were classified as having high ash contents according to ASTM D2974-00 [20]. Both the reported organic and ash contents were in agreement with previously reported studies on Peninsular Malaysian peat soil [21,22]. Moreover, the collected peat was blackish-brown in color , and the in situ von Post humification test categorized the Teluk Intan peat as fibric peat $\left(\mathrm{H}_{3}\right)$. The fiber content test showed an $80.4 \%$ value and verified the samples as fabric peat. The permeability test revealed high fiber content and specific gravity (1.88), which were directly related to the samples' void spaces, as shown in Table 5. 
Table 5. Essential indexed and compaction properties of Teluk Intan peat.

\begin{tabular}{|c|c|c|}
\hline Characteristics & Values & Guidelines \\
\hline Color & Blackish brown & - \\
\hline Moisture content, \% & 224.18 & ASTM D 2974-00 [20] \\
\hline von Post humification & $\mathrm{H}_{3}$ & Landva and Pheeney (1980) [23] \\
\hline Specific gravity, $G_{S}$ & 1.88 & ASTM D 854-14 [24] \\
\hline Liquid limit, LL (\%) & 64.4 & ASTM D4318-10 [25] \\
\hline Permeability, $k_{v}(\mathrm{~m} / \mathrm{sec})$ & $5.86 \times 10^{-5}$ & ASTM D2434-68 [26] \\
\hline pH (peat leachate) @ $20^{\circ} \mathrm{C}$ & 4.0 & ASTM D4972-19 \\
\hline Ash content, AC (\%) & 19.13 & ASTM D2974-00 [20] \\
\hline Organic content, OC (\%) & 80.86 & ASTM D2974-00 [20] \\
\hline Fiber content, FC (\%) & 80.4 & ASTM D 1997-91 [27] \\
\hline \multicolumn{3}{|c|}{ Compaction Properties } \\
\hline Optimum moisture content, OMC (\%) & 31.1 & ASTM D698-12 [16] \\
\hline Maximum dry density, MDD $\left(\mathrm{kg} / \mathrm{m}^{3}\right)$ & 1130 & ASTM D698-12 [16] \\
\hline Unconfined compressive strength, UCS (kPa) & 42.94 & ASTM D2166/D2166M-16 [13] \\
\hline
\end{tabular}

\subsection{Standard Compaction}

The application of hydraulic binders, e.g., SF and OPC, alters the properties of peat. It has significant effects on the density of a treated peat matrix and the water amount required to attain the maximum dry density (MDD), commonly called the optimum moisture content (OMC) [28]. In this light, standard compaction tests were carried out for all the designated combinations of peat and additives to assess their effects on MDD and OMC.

The compaction curves of untreated Teluk Intan peat and peat treated with $10 \%, 15 \%$, and $20 \%$ silica fume (SF) are shown in Figure 1a. The MDD and OMC ( $\left.\mathrm{W}_{\text {opt }}\right)$ of untreated Teluk Intan peat were recorded at about $1130 \mathrm{~kg} / \mathrm{m}^{3}$ and $31.1 \%$, respectively. Figure $1 \mathrm{~b}$ indicates the effects of different percentages of SF on $W_{\text {opt }}$ and MDD. It can be observed that the dry density increased and OMC $\left(\mathrm{W}_{\mathrm{opt}}\right)$ decreased as the amount of silica fume increased. Furthermore, Figure 2 indicates the combined effect of SF and OPC on the compaction curves. It can be observed that the incorporation of SF tended to better reduce the OMC and increase the MDD compared to OPC. This may have been due to the SF particles' fineness and greater surface areas for water absorption. However, all effects of OPC and SF on compaction characteristics are associated with their finer and adhesive natures, which filled up the pores of peat soil and bound the particles together to make a dense matrix, thus increasing the density of the stabilized peat compared to untreated peat. Meanwhile, the lowering of OMC was due to the hydraulic reactions of OPC and SF. The involvement of hydraulic reactions consumed water and subsequently generated heat, so the consumption of water in the peat reduced the optimum water content [29]. In consideration of the swampy environment of peatland, hydraulic binders are suitable for consuming water during the hydration process, thus enhancing peat strength. Similar results have been reported in previous studies on peat stabilization using cement and silica $[7,30,31]$.

\subsection{Mechanical Testing \\ 3.3.1. UCS Development}

The UCS results of untreated peat and 8 designated treated mixes are presented in Figures 3-5. The untreated Teluk Intan peat showed a low strength of about $42.94 \mathrm{kPa}$ due to the high amount of organic matter, which imparted compressible and collapsible characteristics in the parent peat, thus yielding a low compressive strength—as also stated in previous studies [32-34]. 


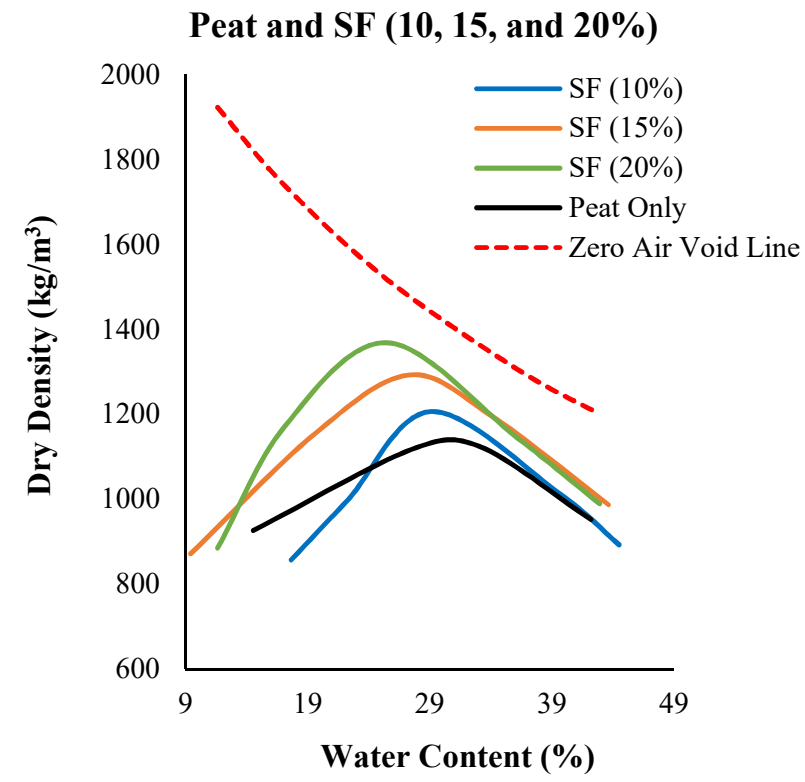

(a)
Effect of Silica fume (SF) on Peat

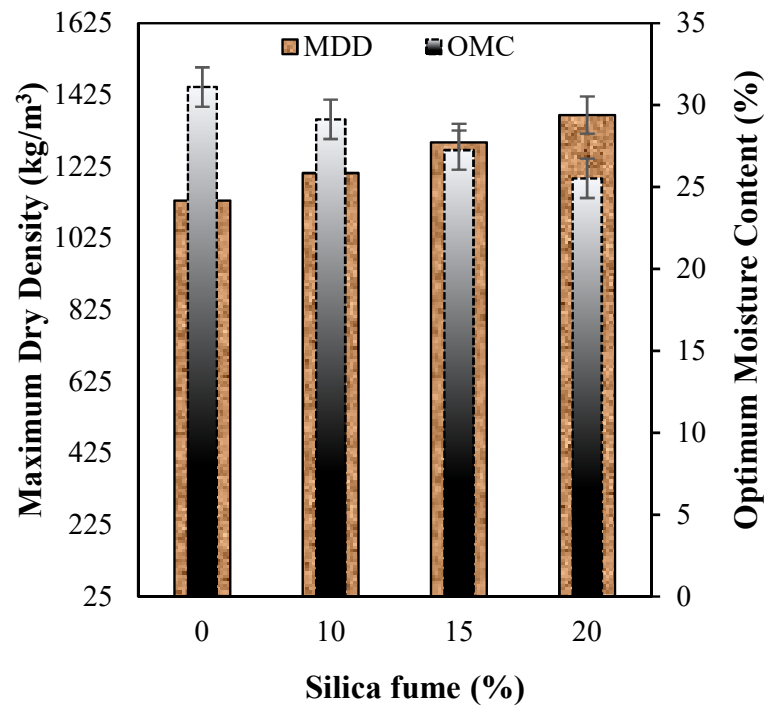

(b)

Figure 1. (a) Standard compaction curves of untreated and treated peat with $10 \%, 15 \%$, and $20 \%$ SF; (b) effects of increasing SF dosage on the dry density and $\mathrm{W}_{\mathrm{opt}}$ of treated peat.

Peat with varing amount of SF and OPC

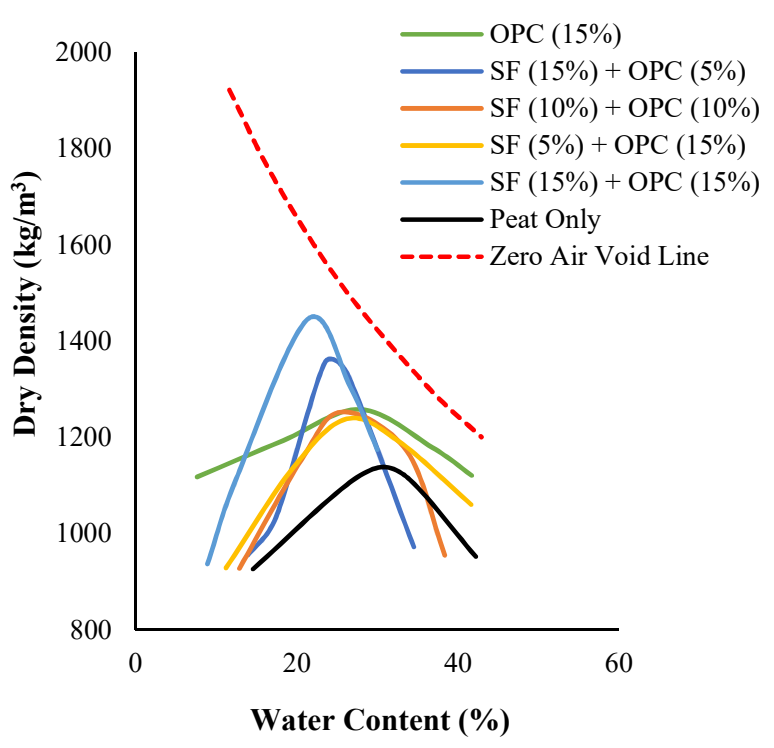

(a)
Effect of varying percentages of OPC and SF on Peat

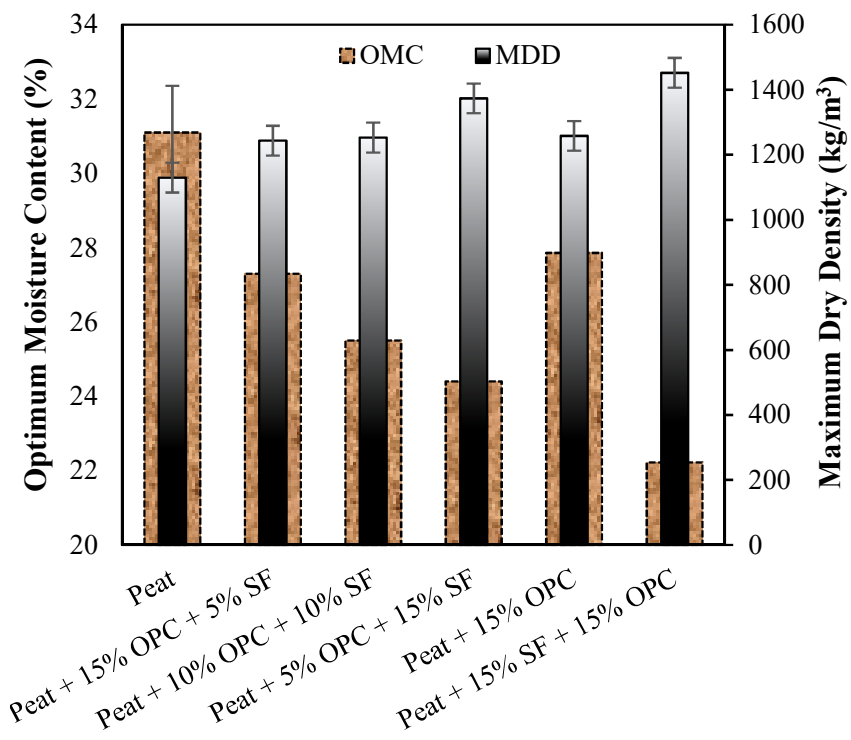

(b)

Figure 2. (a) Standard compaction curves of untreated and treated peat with varying percentages of SF and OPC; (b) effects of varying SF-OPC dosages on the dry density and $\mathrm{W}_{\mathrm{opt}}$ of treated peat. 


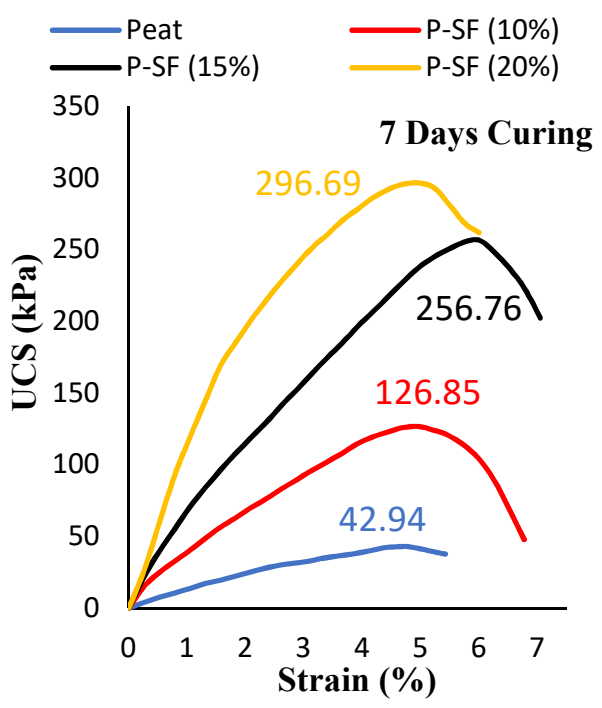

(a)

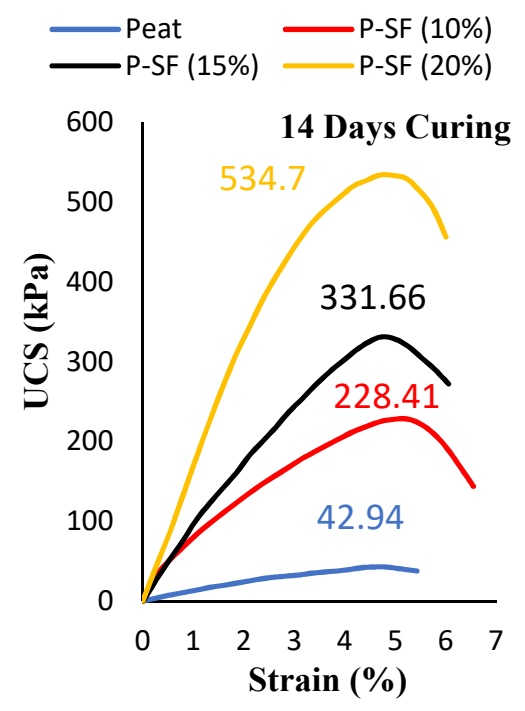

(b)

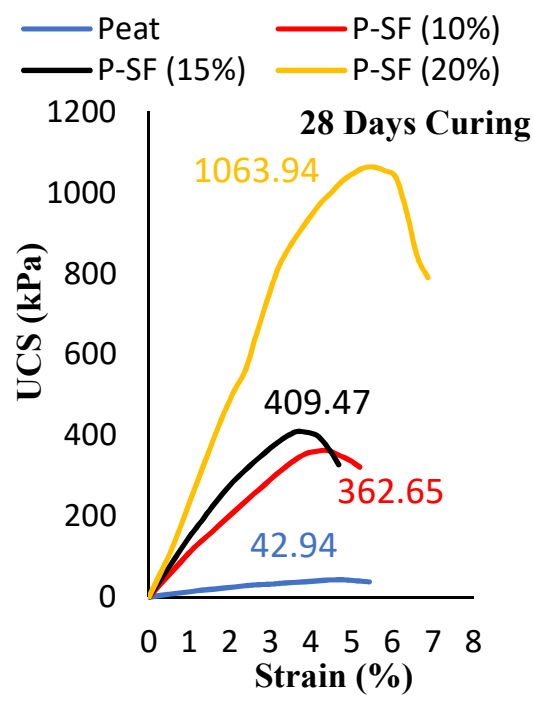

(c)

Figure 3. The unconfined compression strength of $10 \%, 15 \%$, and $20 \%$ SF-stabilized peat under varying curing periods: (a) 7 days, (b) 14 days, and (c) 28 days.

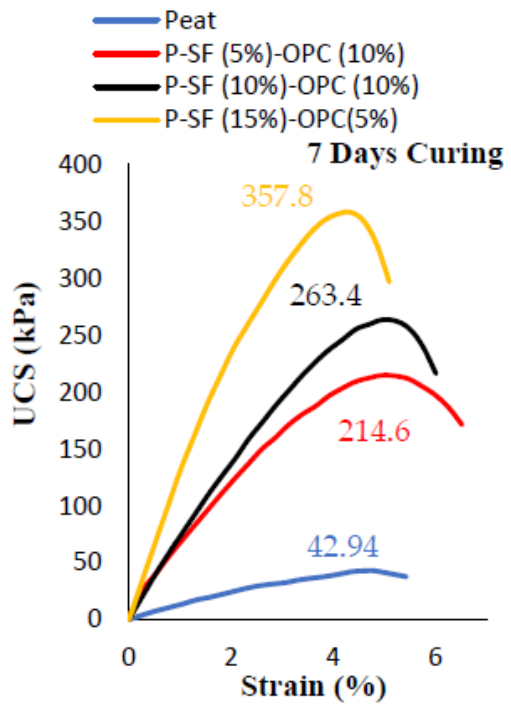

(a)

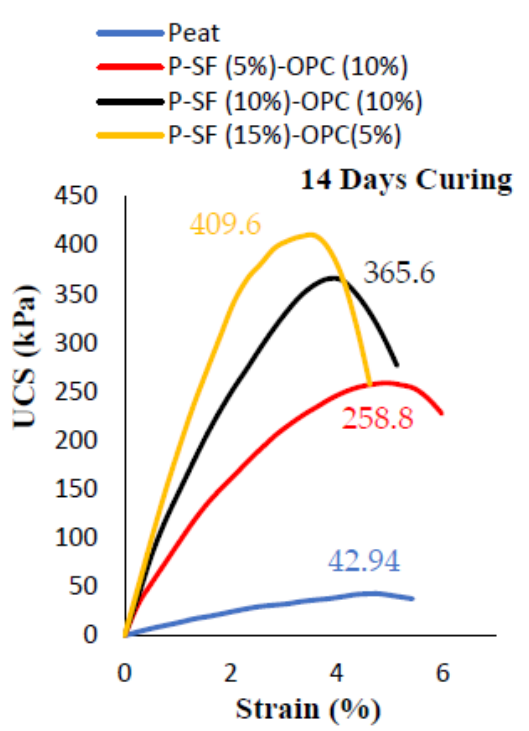

(b)

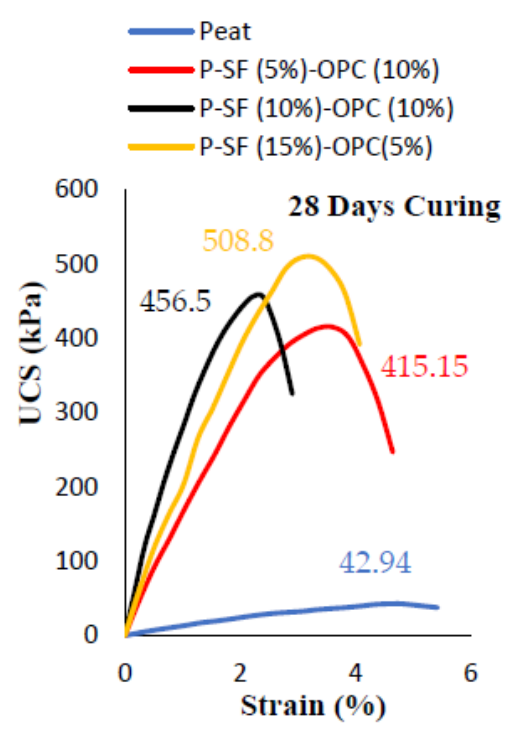

(c)

Figure 4. The unconfined compression strength of SF- and OPC-stabilized peat under varying curing periods: (a) 7 days, (b) 14 days, and (c) 28 days. 


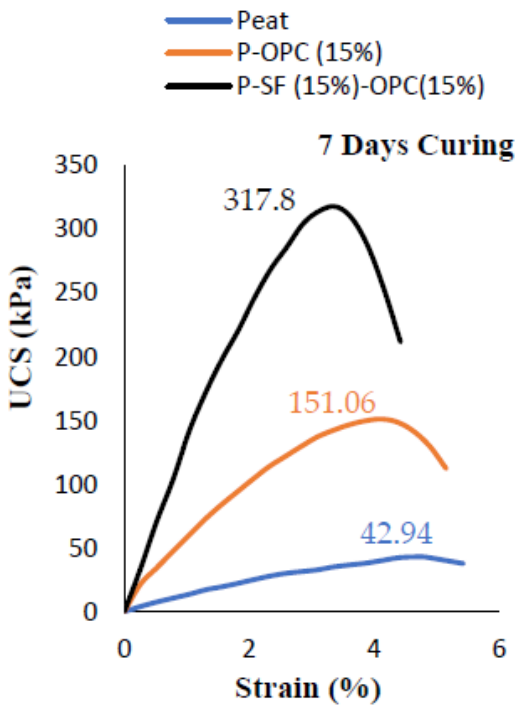

(a)

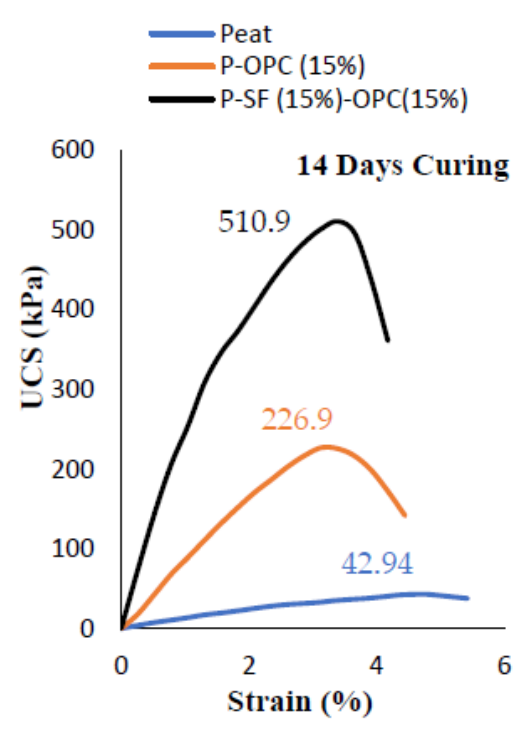

(b)

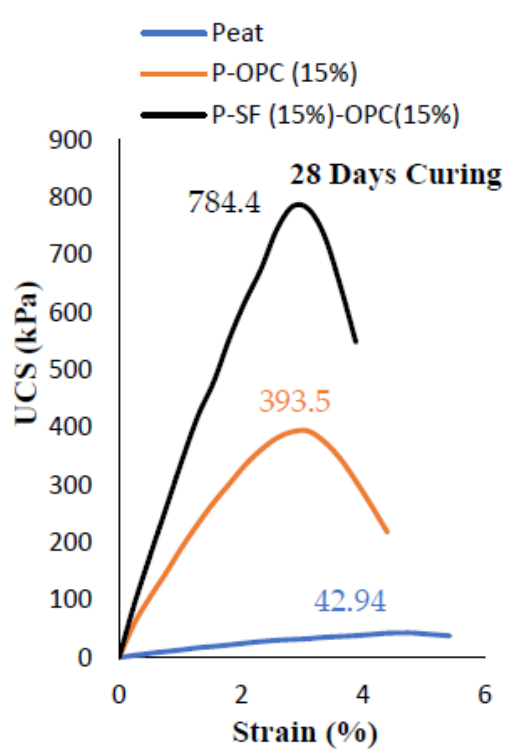

(c)

Figure 5. The unconfined compression strength of untreated peat, 15\% OPC-stabilized peat, and 15\% SF- and 15\% OPCstabilized peat under varying curing periods: (a) 7 days, (b) 14 days, and (c) 28 days.

Various factors, including the type of peat, water content, mineral content, organic, content, fiber content, and $\mathrm{pH}$, affect the strength gain of cement-stabilized peat. The UCS results of the Teluk Intan peat stabilized with varying SF contents (10, 15, and 20\%) and cured for 7, 14, and 28 days are presented in Figure 3a-c. it can be observed that the compressive strength significantly increased as the amount of SF and curing period increased. The highest strength was recorded by mixing $20 \% \mathrm{SF}$ in all curing periods. The highest values of UCS after 7, 14, and 28 days of curing were $296.6,534.7$, and $1063.94 \mathrm{kPa}$, respectively, which also indicated the development of strength as the curing duration was prolonged. The strength enhancement of stabilized peat using silica fume was due to the formation of calcium silicate $(\mathrm{C}-\mathrm{S})$ and calcium silicate hydrate $(\mathrm{C}-\mathrm{S}-\mathrm{H})$ gels [35]. Similarly, the effectiveness of OPC in peat soil has been previously reported [8,36,37]. However, the strength enhancements of SF- and OPC-stabilized peat with curing were different due to the differences in hydration rate. Comparatively, SF led to higher strength enhancements than OPC due to peat's acidic nature, which hindered the stabilization caused by OPC.

Additionally, the detrimental environmental effect of OPC has hindered its applications. For the sake of comparison, OPC was replaced by different amounts of SF for peat stabilization, as shown Figures 4 and 5. To assess the combined effect of SF and OPC, three different mix combinations were made: 5\% SF and 15\% OPC, $10 \%$ SF and 10\% OPC, and $15 \%$ SF and $5 \%$ OPC. The cumulative quantity of binders was kept at $20 \%$ because the highest strength of Teluk Intan peat was achieved with 20\% SF content. Moreover, Kalantari et al. [8] suggested a 20\% cumulative OPC and SF binder for peat stabilization. Figure $4 a-c$ shows the 7,14 , and 28 day curing-strengths of SF $(5,10$, and $15 \%)$ and OPC $(5,10$, and 15\%), respectively. Figure 5. indicates the strength obtained by using 15\% SF, as advised by Kalantari et al. [8], and a trail mix of adopting 15\% OPC and 15\% SF. It can be observed that the achieved strength was higher than the parent peat due to its fine pozzolanic nature. However, the gained strength was still lower than the strength obtained when using 20\% SF. Comparatively, the strength gained by using SF was higher compared to that gained by using OPC; this may have been due to the extremely fine size of silica fume, which is also approximately 120-200\% more pozzolanic than OPC [35]. Moreover, the presence of humic acid in peat soil reduces the efficiency of OPC by retarding strength enhancement. For this reason, Axelsson et al. [38] suggested utilizing a surplus amount of OPC to neutralize the humic acid. Thus, using SF (a waste material and effective binder) to 
enhance the strength of peat is a more cost-efficient and sustainable solution than using OPC. Combining SF and OPC for strength development is associated with pozzolanic reactions and the development of calcium silicate (CS), calcium aluminate hydrate (C-A-H), calcium silicate hydrate $(\mathrm{C}-\mathrm{S}-\mathrm{H})$ bonds, and ettringite (AFt) formation $[7,8,39]$.

\subsubsection{Strength Development by Various Mix Designs}

ASTM D 4609 (Standard Guide for Evaluating Effectiveness of Admixtures for Soil Stabilization) specifies a UCS value of $345 \mathrm{kPa}$ for a stabilized soil to be considered an effective binder, as shown in Figure 6 [29]. As such, the strength development index (SDI) obtained with Equation (1) is used, to assess the influence of various mix designs on peat strength [40].

$$
\mathrm{SDI}=\frac{\text { Max. UCS (stabilized) }- \text { Max. UCS (parent) }}{\text { Max. UCS (parent) }}
$$

where Max. UCS (stabilized) and Max. UCS $($ parent) indicate the ultimate unconfined compressive strength of treated and untreated peat, respectively.

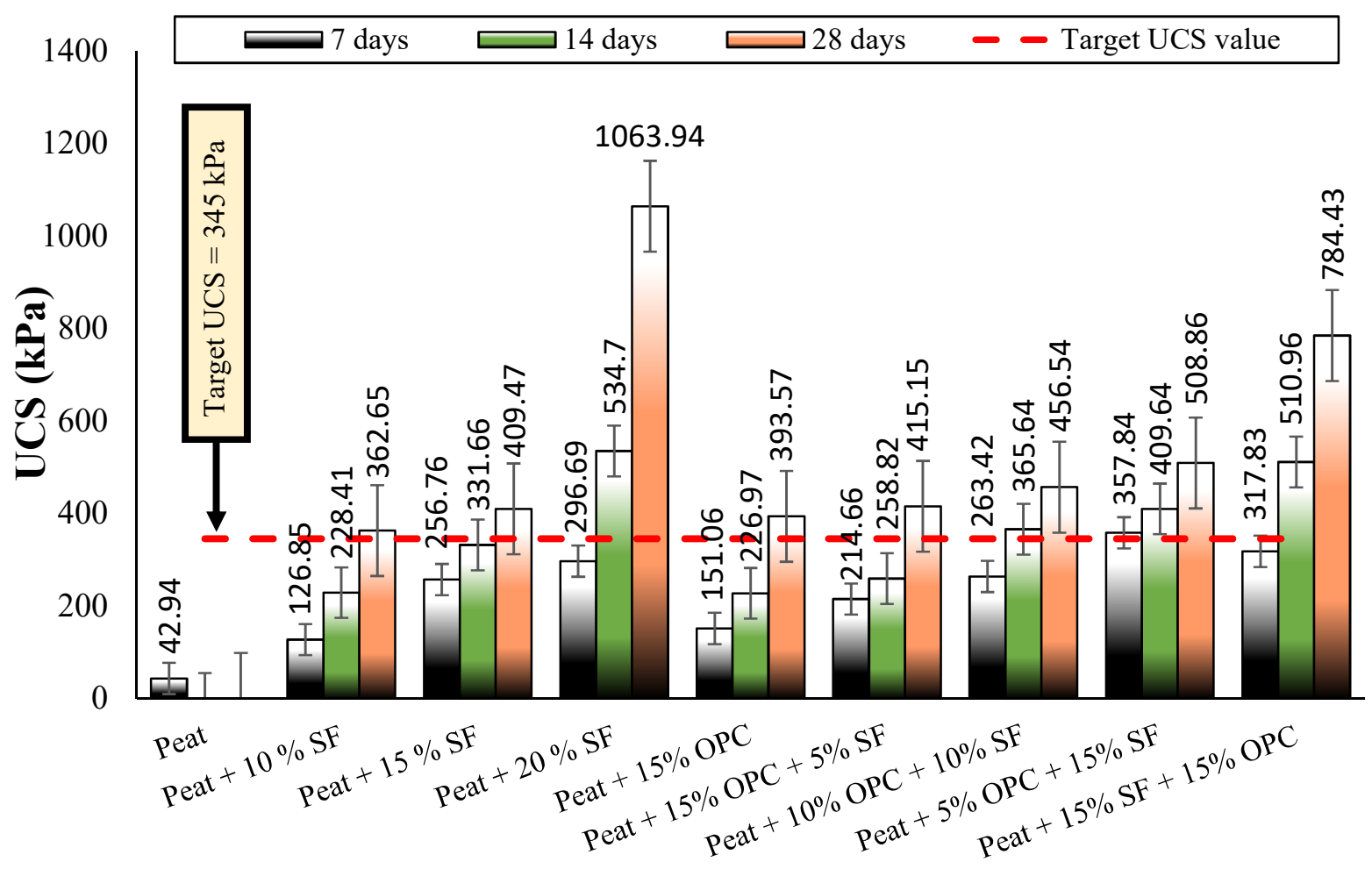

Figure 6. Comparing the compressive strength of untreated peat and stabilized peat after 7, 14, and 28 days of curing.

Figure 7 shows the SDI results of stabilized and parent peat cured for 7, 14, and 28 days. Based on the untreated peat UCS value $(42.94 \mathrm{kPa})$ and the targeted UCS value (345 kPa), an SDI of 7.03 was calculated, as indicated in Figure 7. It was observed that the parent peat and almost all stabilized peat cured for 7 days fell below the targeted unconfined compression strength. After extending the curing period to 14 days, several mixes met the minimum strength criteria: peat and $20 \% \mathrm{SF}$; peat, $10 \% \mathrm{SF}$, and $10 \%$ OPC; peat, $5 \%$ OPC, and $15 \%$ SF; and peat, $15 \%$ OPC, and 15\% SF. All the stabilized peat mixes met the minimum UCS criteria advised by ASTM D 4609 after 28 days of curing, as shown in Figures 6 and 7. A slower development of UCS when using OPC compared to when using SF was observed here and previously in [41]. Considering the targeted SDI value of 7.03, both OPC treated peat cured for 28 days and SF treated peat cured for 14 days encouraged subgrade improvement. 


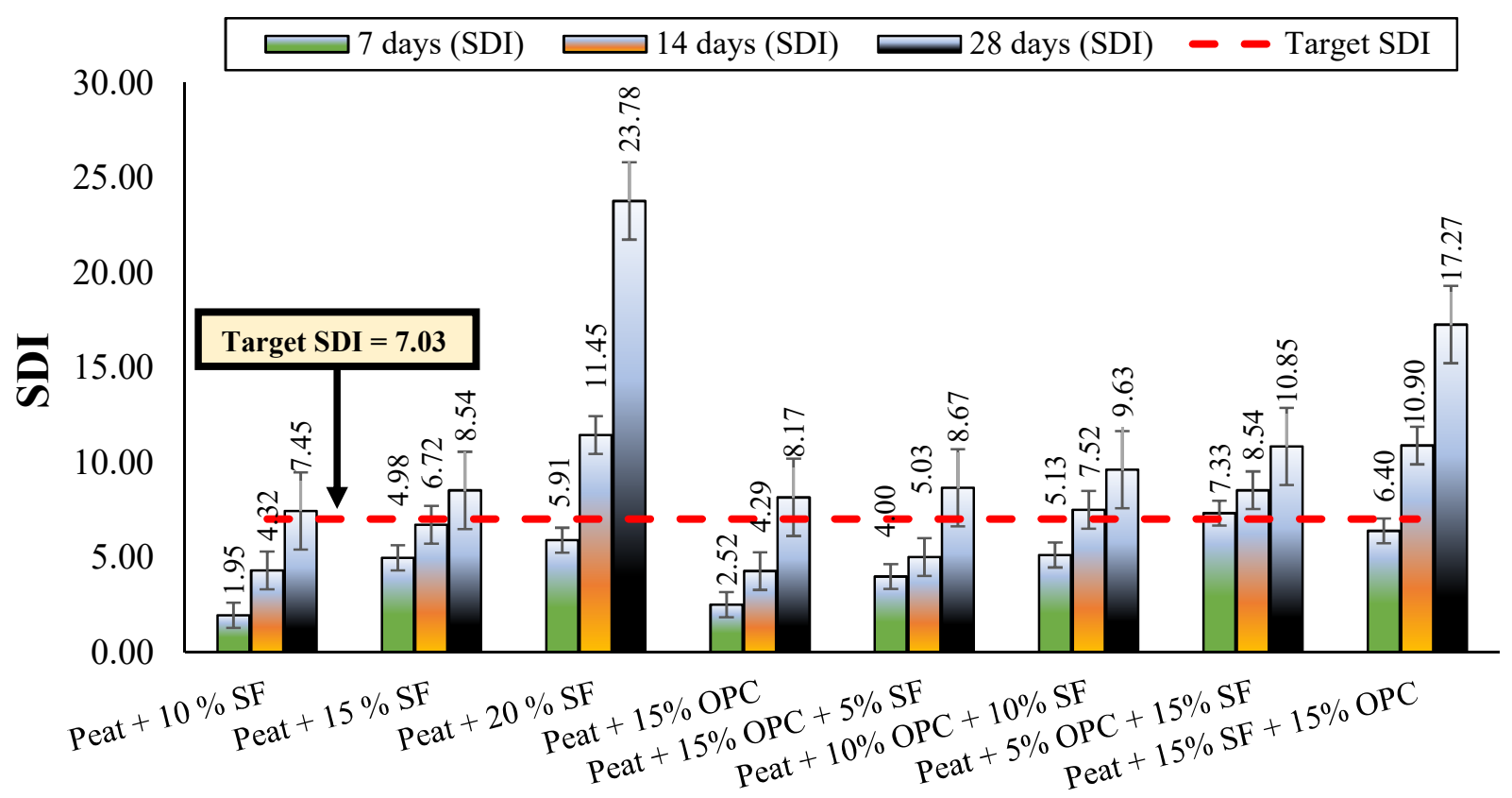

Figure 7. Strength development index (SDI) of all mixes after 7, 14, and 28 days of curing.

\subsubsection{Binder's Effect on the Failure Modes}

The presence of fibers and partially decomposed vegetation induces structural anisotropy in peat, thus affecting the compression modes of failure [42]. The failure modes of the parent Teluk Intan peat and stabilized peat are presented in Figure 8. It can be observed that the failure pattern changed with the stabilization of peat. Moreover, the failure behavior changed with binder dosages due to changes in density [43].

Due to the high fiber and organic content, the parent peat underwent bulging with an unrecognized failure plane upon axial compressive loading, as shown in Figure 8. However, it was observed that the utilization of hydraulic binders increased stiffness and thus led to a change in the failure mode. This type of failure mode is associated with ductile behavior [44]. The bulging failure mode subsided, and a compressive Vshaped failure pattern was observed in the $10 \%$ SF and 15\% OPC treated UCS samples, which indicated a reduction in the ductility with the use of a hydraulic binder. On the other hand, a clear shear failure pattern was noticed in the $15 \%$ SF treated peat due to its increased stiffness causing brittleness. In the same way, steep sheerness and high brittleness with bursting failure, causing the destruction of the entire UCS specimen, were observed in the $20 \%$ SF treated peat and the $15 \%$ SF and $15 \%$ OPC treated peat, as shown in Figure 8. This means that the incorporation of higher hydraulic binders caused a predominant failure plane that induced brittleness. This brittle behavior has been previously reported to be caused by increasing amounts of hydraulic binder [44,45]. Additionally, nonrecognizable compressive collapsible failure was noticed in the 5\% OPC and 15\% SF, 10\% OPC and 10\% SF, and 15\% OPC and 5\% SF treated peat, as shown in Figure 8, indicating its structural heterogeneity. Thus, additives such as fibers, shredded tires, and geofoam materials are recommended in tandem with hydraulic binders in peat to limit brittle and collapsible failure. 

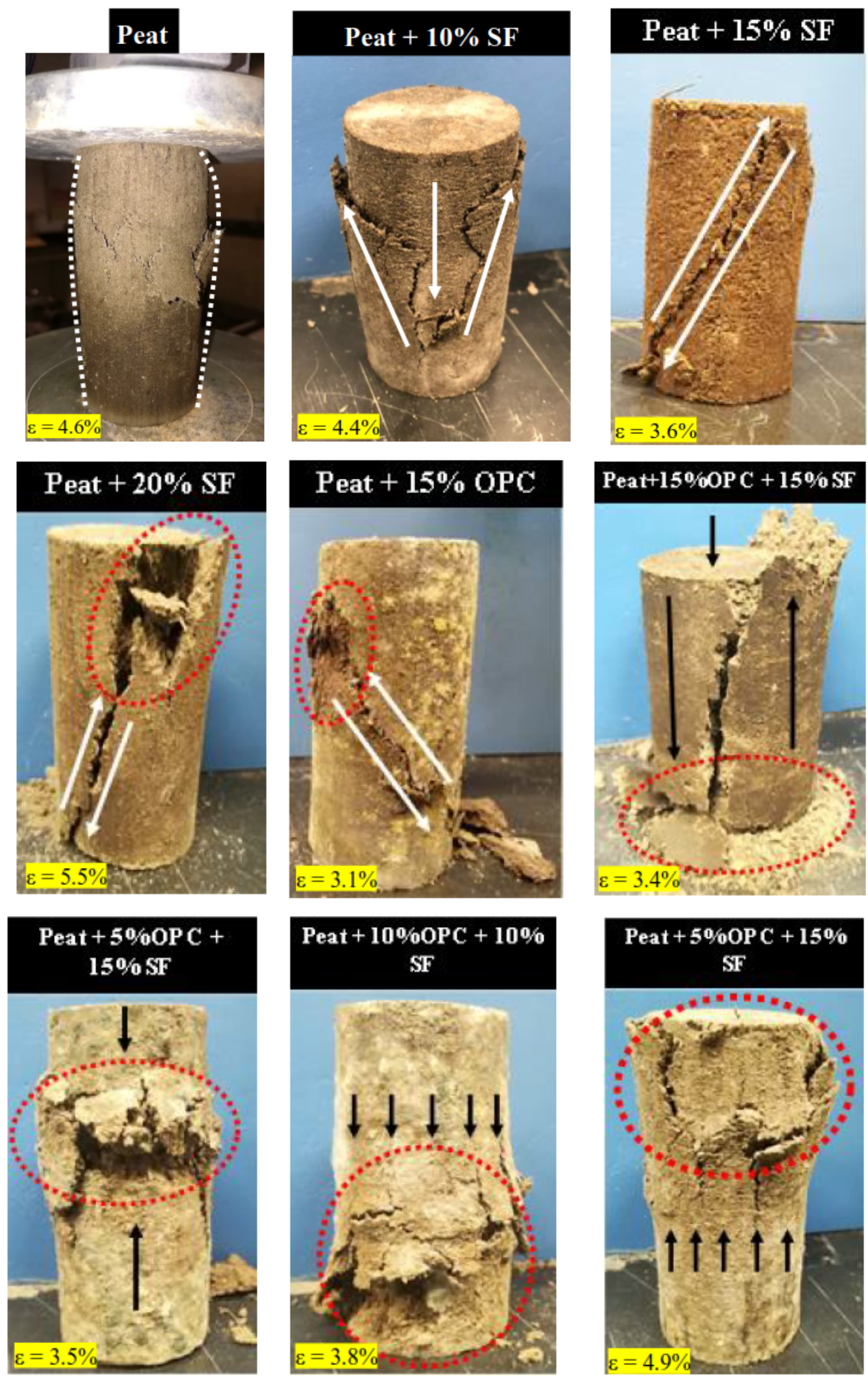

Figure 8. Failure modes of the stabilized and parent peat. 


\subsubsection{CBR and Comparison}

The CBR test is an essential test conducted to estimate the shearing resistance (strength) of a subgrade or subbase of pavement. It is used to examine the durability, efficiencies, and thus overall performance of a pavement foundation material. The subgrade can either be a natural existing ground (original subgrade) or an embankment constructed from borrowed material (new subgrade). In both cases, the minimum permissible CBR value for subgrade is $10 \%$ [46], and the relative ratings of the shearing resistance based on CBR values are given in Table 6 [47].

Table 6. Relative ratings of CBR values for subgrade.

\begin{tabular}{ccc}
\hline Material & CBR Value (\%) & Rating/Remarks \\
\hline Subgrade & $<5$ & Very poor \\
Subgrade & $5-10$ & Poor-fair \\
Subgrade & $10-20$ & Fair-good \\
Subgrade & $20-30$ & Very good \\
\hline
\end{tabular}

The soaked and unsoaked CBR values of treated and untreated Teluk Intan peat cured for 7, 14, and 28 days are presented in Figures 9-11, respectively. The parent Teluk Intan peat showed extremely low soaked and unsoaked CBR values of $1.1 \%$ and $3.1 \%$, respectively. In the literature, the unsoaked CBR value of undisturbed peat has been shown to be as low as $0.785 \%$ [48] and ranging from 2.43 to $5.66 \%$ [49-51]. The Table 6 ratings suggest that Teluk Intan peat very poor in strength for subgrade materials and need to be treated to enhance their shearing resistance.

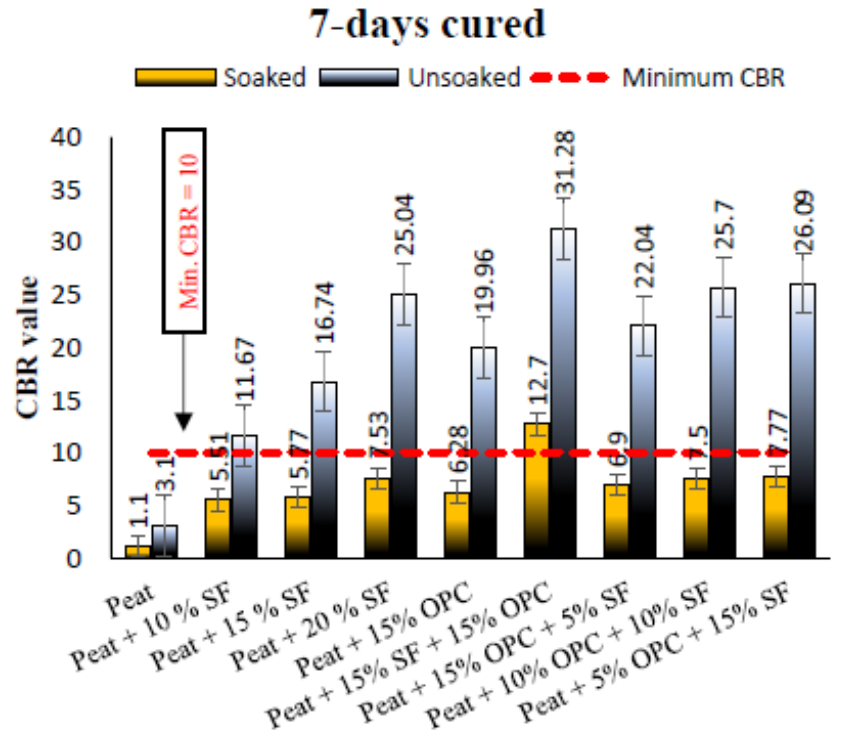

(a)

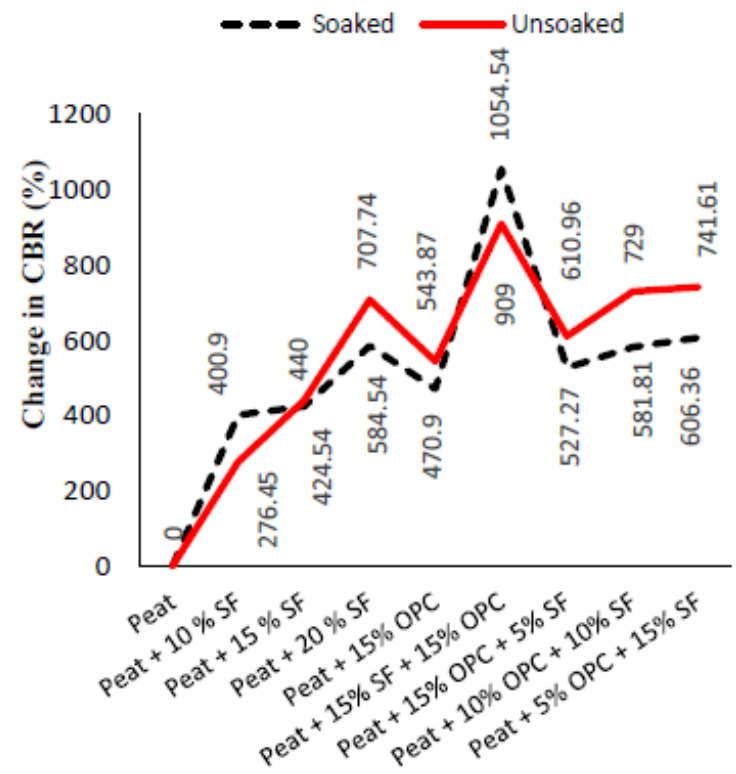

(b)

Figure 9. (a) The 7 days cured soaked and unsoaked CBR values of treated and untreated Teluk Intan peat; (b) changes in soaked and unsoaked CBR values after treatment. 


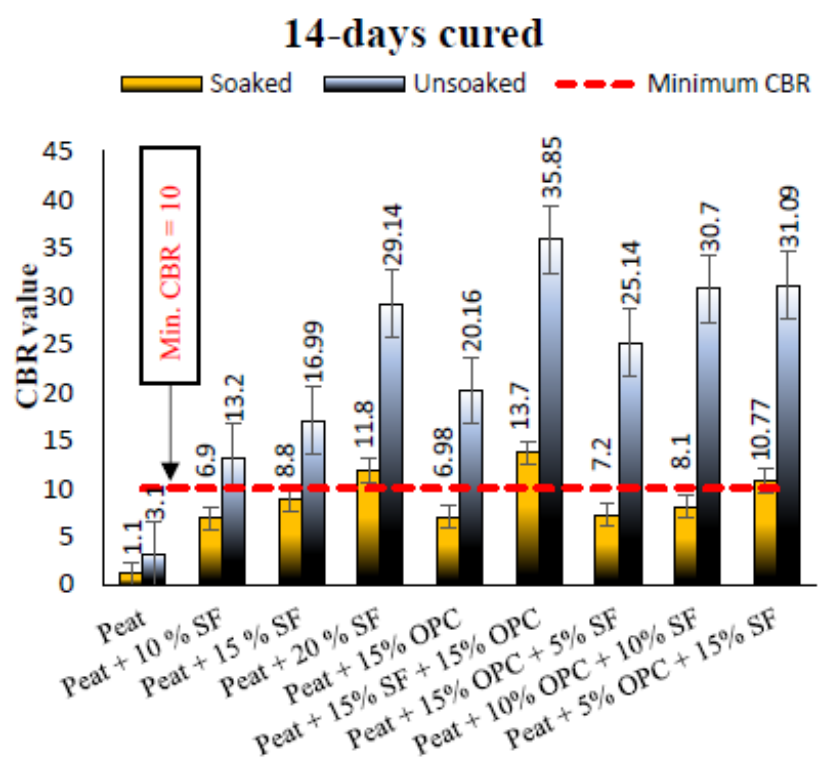

(a)

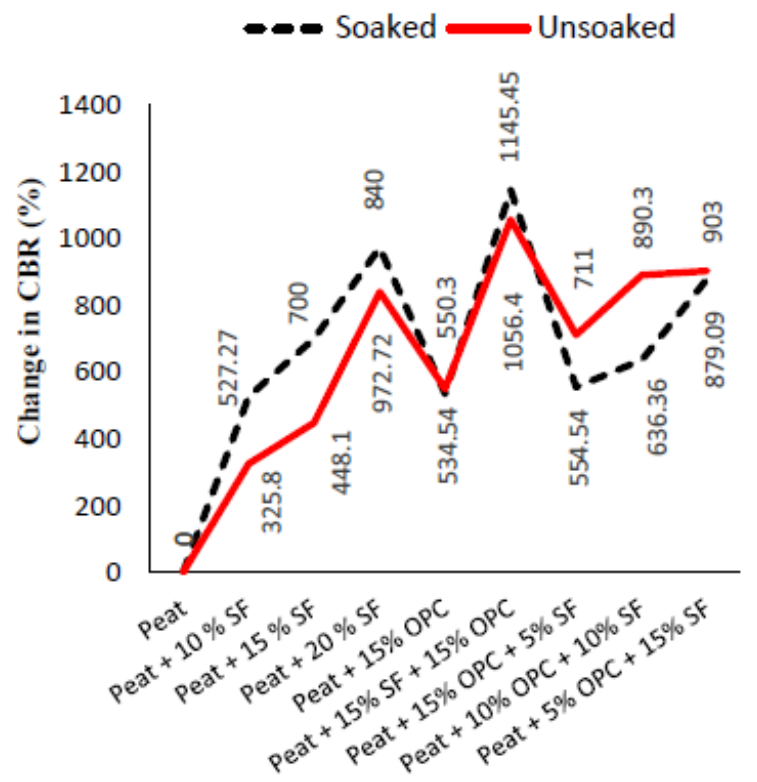

(b)

Figure 10. (a) The 14 days cured soaked and unsoaked CBR values of treated and untreated Teluk Intan peat; (b) changes in the soaked and unsoaked CBR values after treatment.

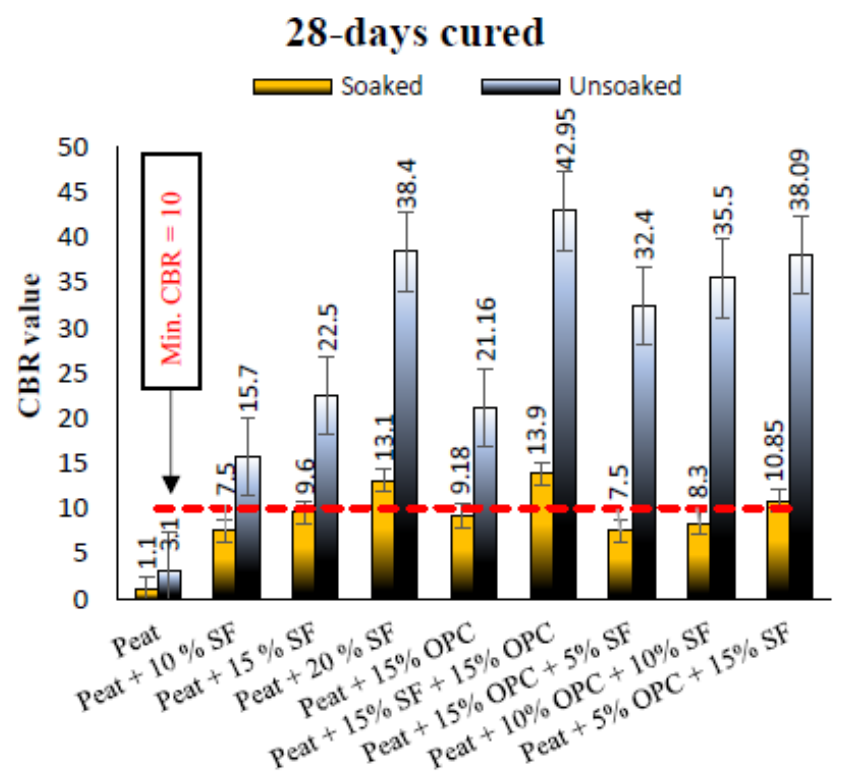

(a)

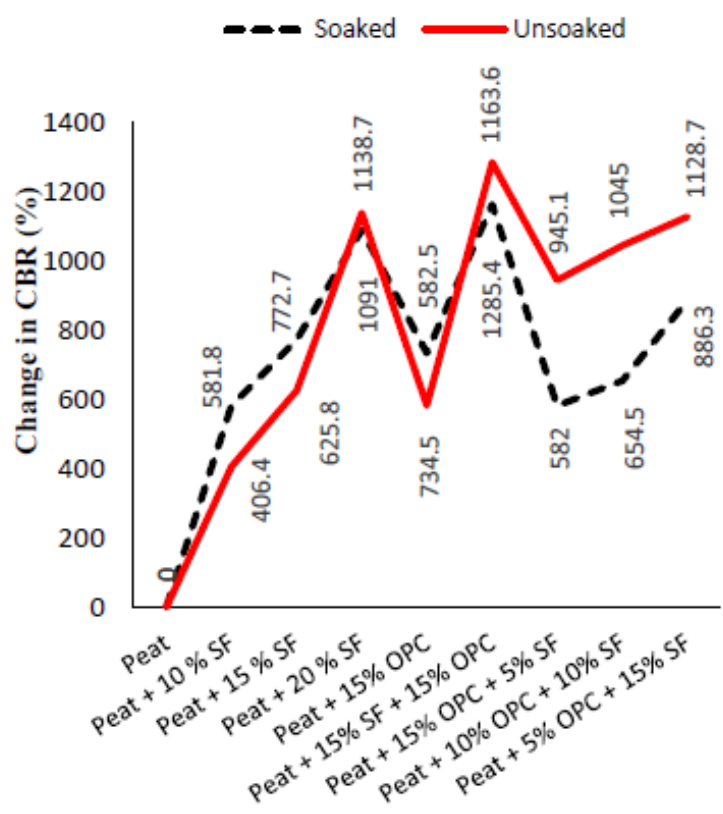

(b)

Figure 11. (a) The 28 days cured soaked and unsoaked CBR values of treated and untreated Teluk Intan peat; (b) changes in the soaked and unsoaked CBR values after treatment.

The treatment of Teluk Intan peat with hydraulic binders (SF and OPC) showed substantial improvements of the CBR value after curing for 7,14 , and 28 days. As noticed in Figure 9a, all the designated mixes obtained a higher unsoaked CBR value than 10 after 7 days of curing, which indicated their suitability as subgrade materials. The highest CBR value of the specimens cured for 7 days specimens was obtained by treating peat with $15 \% \mathrm{SF}$ and $15 \%$ OPC, as shown in Figure 9b. Similarly to UCS, CBR was increased after prolonging the curing period due to pozzolanic reactions, as shown in Figures 10 and 11. Moreover, the CBR of the stabilized peat increased with the increasing SF and OPC contents. Even the 
soaked samples of peat; $20 \%$ SF and peat; and 15\% OPC, and 15\% SF achieved CBR values of more than 10, indicating their feasibility as subgrade materials. The observed strength enhancement due to SF may be associated with the formation of calcium silicate hydrate (C-S-H) gel and calcium silicate (CS) [7,52], while the combined effect of SF and OPC may be associated with the formation of calcium silicate (CS) and hydrated components as a result of hydration, i.e., calcium aluminate hydrate $(\mathrm{C}-\mathrm{A}-\mathrm{H})$, calcium silicate hydrate (C-S-H) gel, and AFt formation. [1]. Moreover, the development of greater interfacial confinement bonding, roughness, contact area, and friction mobilization upon the loading of the stabilized peat yielded higher CBR values [53]. Comparatively, the strength gains caused by the combined SF and OPC was higher than the other treatments. About 1054\%, $1145 \%$, and $1163 \%$ CBR was recorded by $15 \%$ SF and $15 \%$ OPC treated peat after curing for 7,14 , and 28 days of curing, respectively. However, OPC is expensive and causes environmentally hazardous effects, so its adoption is discouraged. Therefore, SF, which is an industrial by-product waste that is cementitious, is a more sustainable and cost-effective binder than OPC.

\subsection{Morphological Variations}

SEM was used to reveal the morphology of the parent and treated Teluk Intan peat. The internal mineralogical formation upon the application of hydraulic binders, i.e., silica fume (SF) and OPC, significantly alter the strength of the peat soil.

It can be observed in Figure 12a that the internal structure of the parent peat consisted of hollow cavities/pores that were flaky and loosely packed, as well as spongy organic matter. Typically, organic matter is hollow and spongy in nature, so they possess a high water-holding capacity upon saturation $[10,33]$. The same morphology of Malaysian peat has been reported by other researchers [10,30,54-57]. These are the features of parent Teluk Intan peat that are responsible for its low UCS and CBR values, as observed during the mechanical testing. On the other hand, a more dense and compacted microstructure compared to parent peat was observed in the 28 days cured SF peat and the SF- and OPCstabilized peat, as shown in Figure $12 b, c$, respectively. The formation of hydration products, i.e., $\mathrm{C}-\mathrm{S}-\mathrm{H}$ gel, $\mathrm{C}-\mathrm{A}-\mathrm{H}$, and Aft, caused a reduction in the micropores, thus yielding a dense and compact matrix of peat that reasonably enhanced its strength $[54,58,59]$.

\subsection{Statistical Correlations}

To elucidate the interdependency of SF-stabilized peat soil parameters, the statistical correlations among the UCS, CBR (soaked and unsoaked), and SF content were evaluated. The use of correlations is a well-established and widely adopted technique to investigate the effect of one parameter on others. Moreover, it can be used to indicate the closeness of experimentally investigated values to a tailored trend (regression) line that ranges from 0 to 1 via the coefficient of determination $\left(R^{2}\right)$. Generally, any regression model that possesses an $\mathrm{R}^{2}$ value equal to or close to 1 is considered a more effective predictive model than one near zero. Several studies have adopted the statistical correlation method to identify the effect of one parameter on others [60-62].

\subsubsection{Compaction Parameters Correlations}

The OMC and MDD have significant effects on the engineering properties of soil. A highly significant statistical correlations $\left(R^{2}>0.96\right)$ among the compaction parameters and the increasing amount of silica fume, as shown in Figure 13. In Figure 13a, two linear significant regression models can be seen, thus indicating an increasing trend in the maximum dry density and a decreasing trend in the OMC with the increased amount of SF content. Moreover, a significant correlation among the OMC and MDD of SFstabilized peat were observed in the range of $10-20 \%$ of silica fume content, as illustrated in Figure 13b. It can be seen that MDD predominantly decreased with the increasing amounts of OMC, which could also be clearly observed in the mechanical characteristics. 


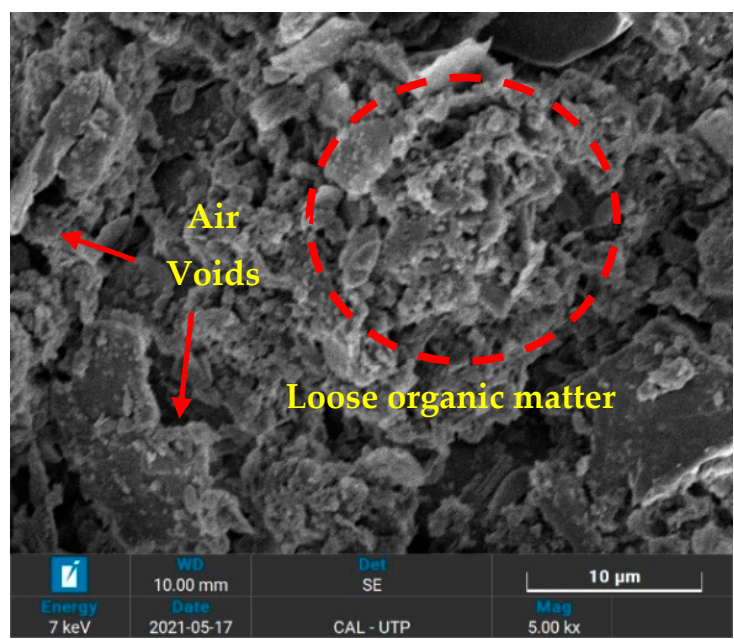

(a)

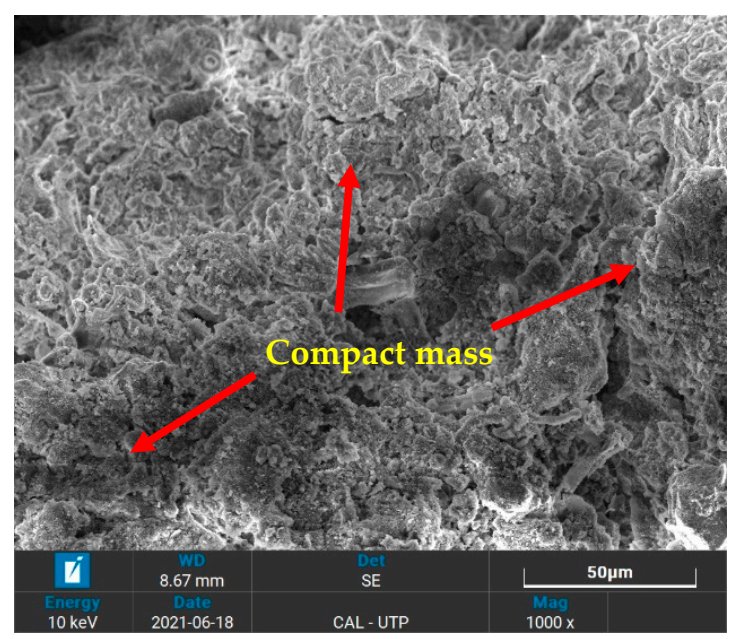

(b)

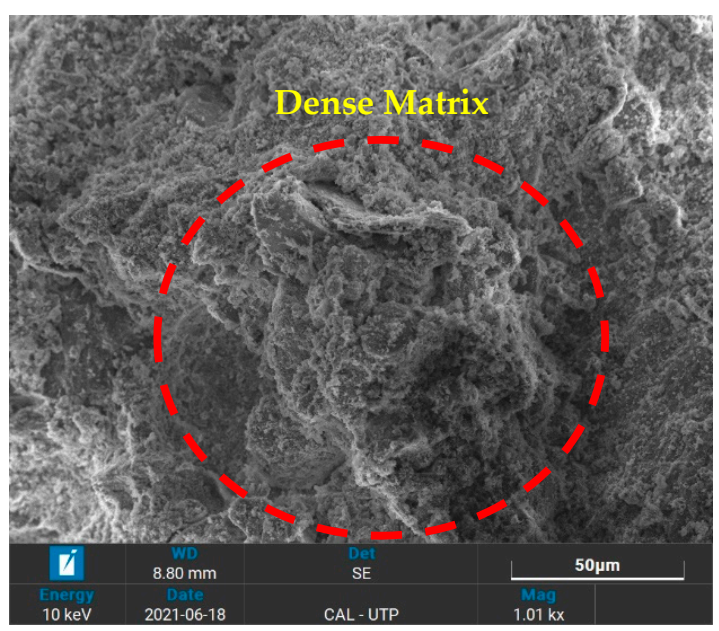

(c)

Figure 12. Micrographs of treated and untreated peat: (a) peat; (b) peat and SF; and (c) peat, SF, and OPC.

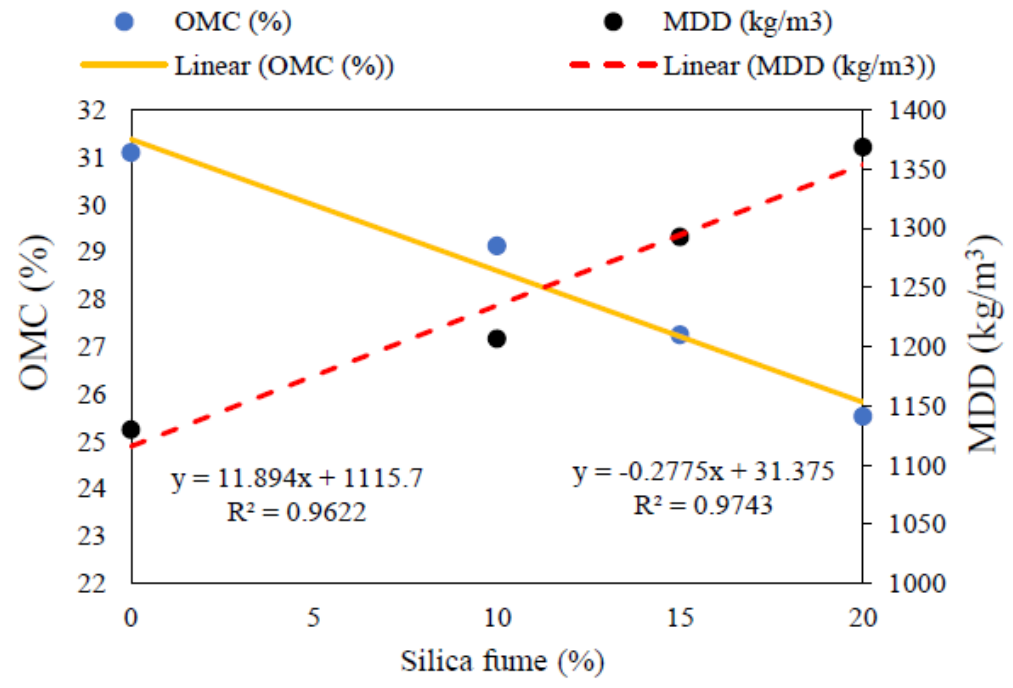

(a)

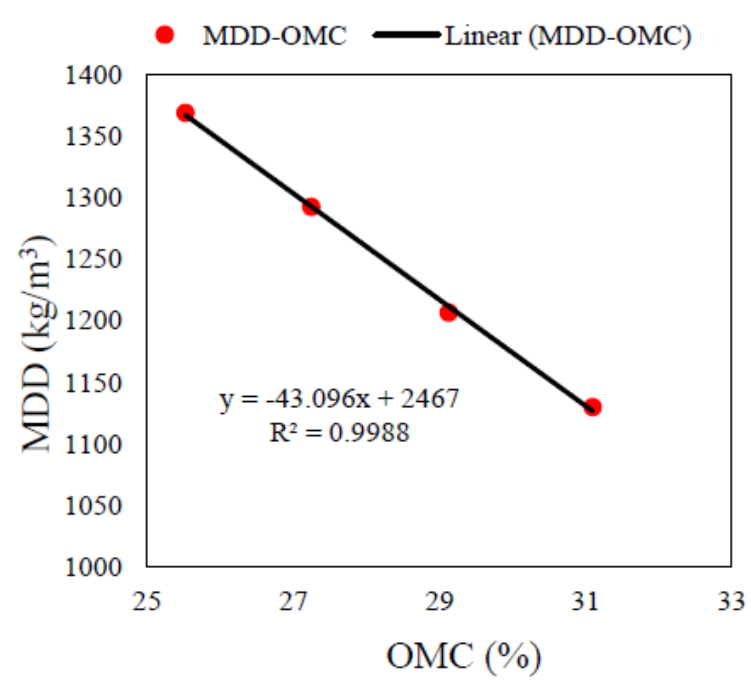

(b)

Figure 13. Statistical correlation among the peat compaction parameters: (a) variation of OMC and MDD with SF content and (b) variation of MDD with the OMC of SF-stabilized peat. 


\subsubsection{Mechanical Strength Parameters and Binders Dosage Effects}

Binder content plays a vital role in peat stabilization, as observed from our mechanical property testing and previous studies. Figures 14 and 15 illustrate the statistical correlations among UCS-SF, CBR-SF, and UCS-CBR content, respectively. Figure 14 shows a strong quadratic model $\left(\mathrm{R}^{2}>0.90\right)$ among the UCS and SF contents for the 7, 14, and 28 day curing periods. Using Equations (2)-(4), the unconfined compression strength was predicted for the stabilized peat cured for 7,14 , and 28 days, respectively.

$$
\begin{gathered}
(\mathrm{UCS})_{7 \text { days }}=13.336 \times(\mathrm{SF})+30.78 \\
(\mathrm{UCS})_{14 \text { days }}=23.56 \times(\mathrm{SF})+19.377 \\
(\mathrm{UCS})_{2 \text { days }}=2.8393 \times(\mathrm{SF})^{2}-9.4609 \times(\mathrm{SF})+61.567
\end{gathered}
$$

Similar to UCS-SF content relationship, effective models were developed to predict the CBR values (soaked and unsoaked) of varying SF contents after curing stabilized peat for 7, 14, and 28 days, as shown in Figure 15a-c. Likewise, the regression models shown in Figure 16a-c were developed among the UCS and CBR (soaked and unsoaked) of $10-20 \%$ SF-stabilized peat after 7, 14, and 28 days of curing. All the developed models were statistically significant and could be adapted to predict the UCS and CBR values of stabilized peat that incorporates $10-20 \%$ of SF.

Moreover, the statistical mean differences among the soaked and unsoaked CBR values after 7,14 , and 28 days of curing were obtained with a Student's t-test, which is a widely adopted statistical test that was developed by William Sealy Gosset in 1905. It is used to investigate significant differences between the means of two sets of data, with a significance level of $0.05(\alpha=0.05)$. Several remarkable studies have used the t-test to assess statistically significant differences among experimental data [63-65]. Table 7 shows the variability of the CBR results and the effect of soaking on the CBR value after 7,14 , and 28 days of curing. It can be observed that the statistically significant differences between the soaked and unsoaked CBR values vanished as curing time increased. This may have been due to the hydration of SF causing the matrix of peat to be cemented after proper curing, thus reducing the strength-degrading effect of soaking.

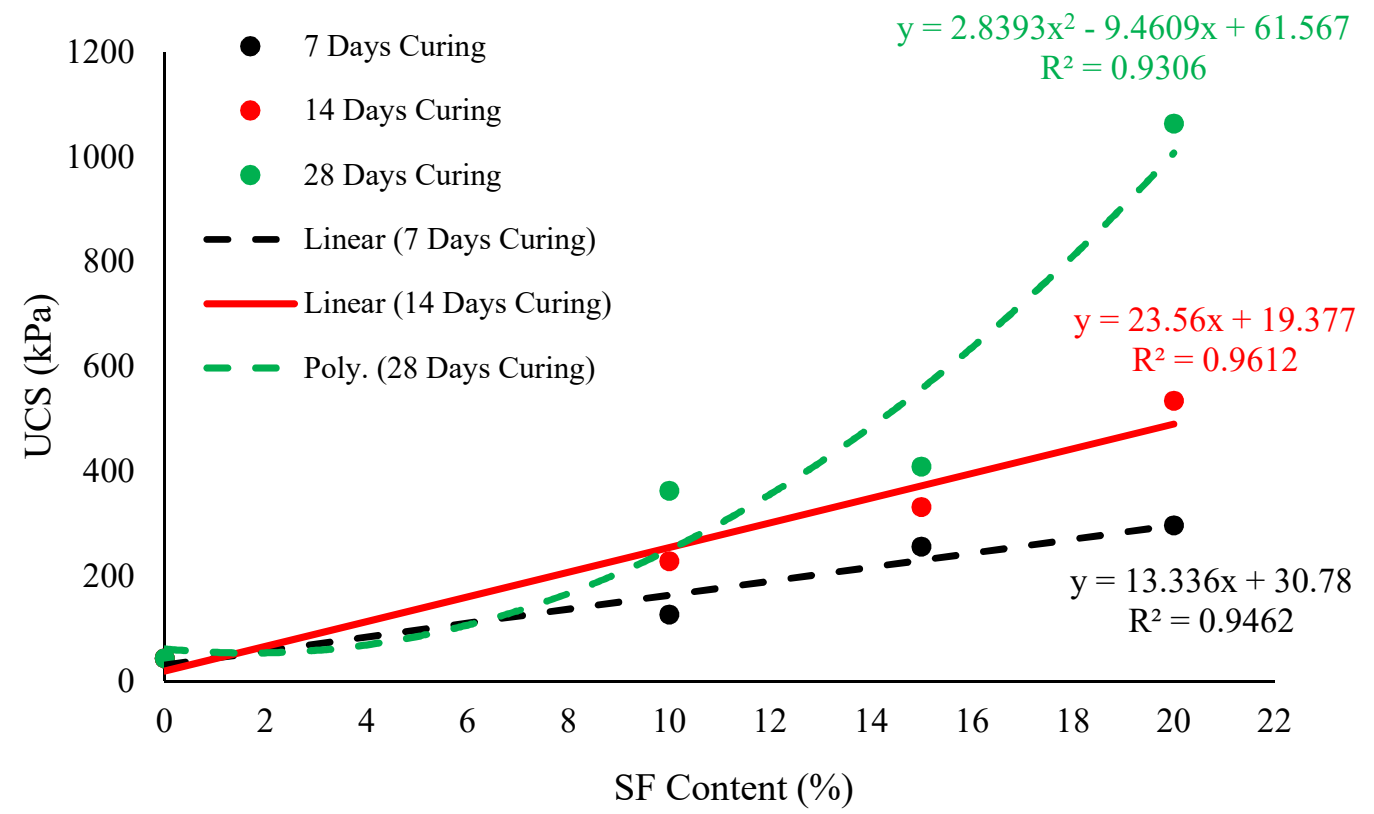

Figure 14. The statistical relationship between the increasing amounts of SF and UCS obtained after 7, 14, and 28 days of curing. 


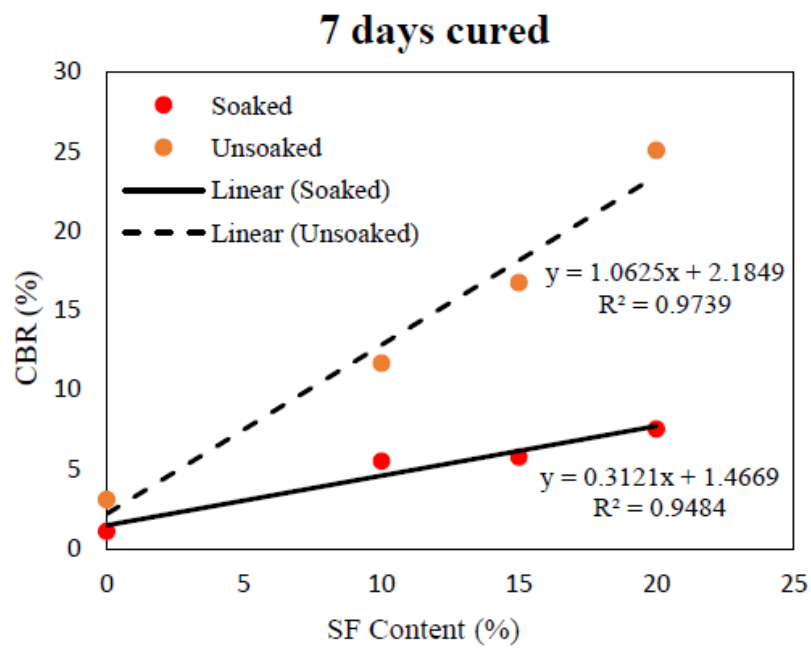

(a)

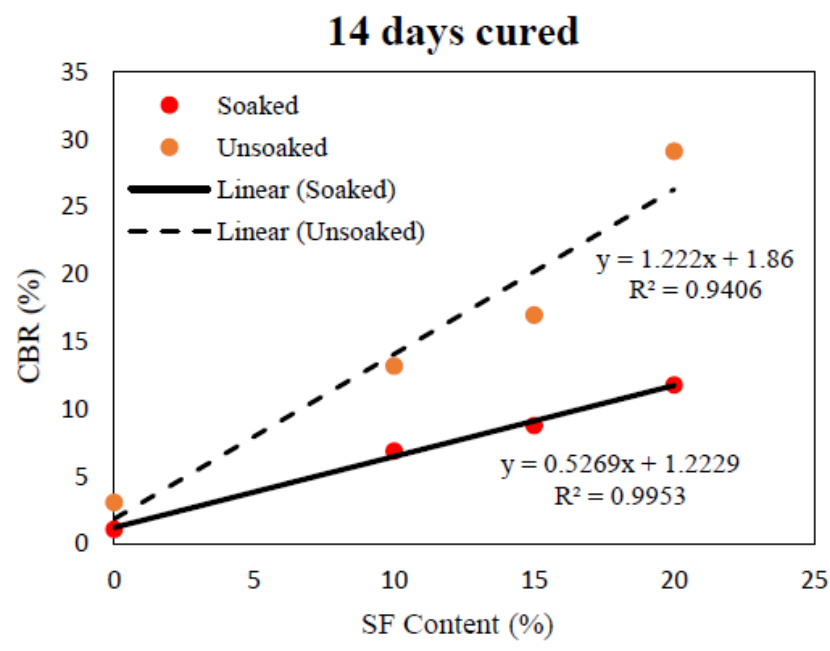

(b)

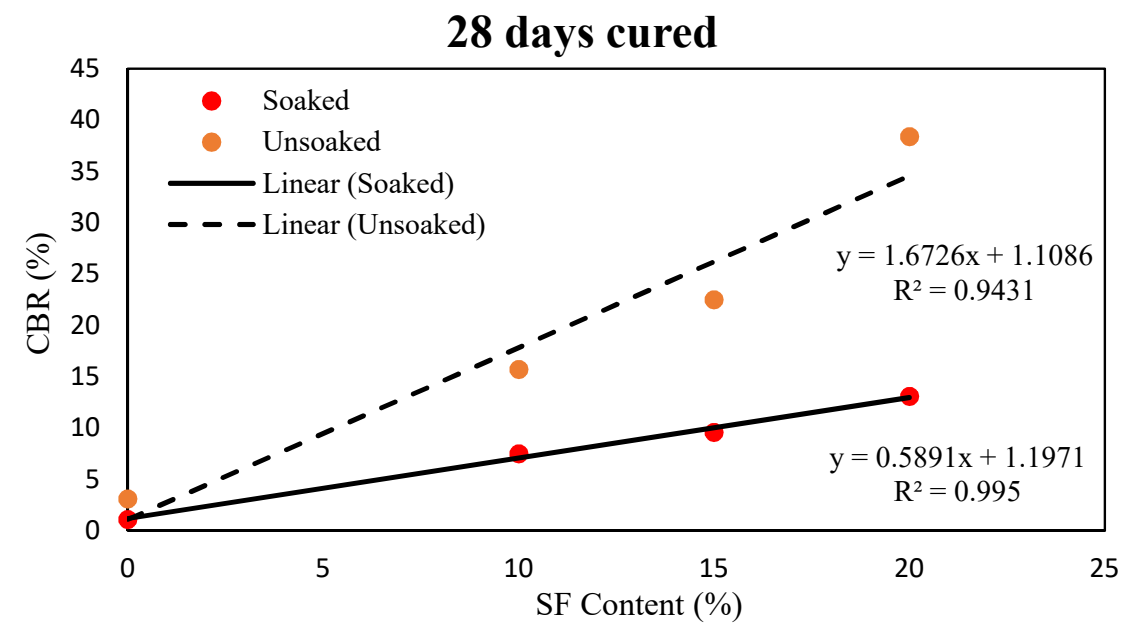

(c)

Figure 15. Statistical relationship between increasing amounts of SF and CBR (soaked and unsoaked) obtained after 7 (a), 14 (b), and 28 (c) days of curing.

Table 7. Statistical analysis results for the verification of the variable similarity of CBR values (soaked and unsoaked) of 7, 14, and 28 days of curing.

\begin{tabular}{cccc}
\hline & 7 Days & 14 Days & 28 Days \\
\hline Mean & 6.27 & 9.17 & 10.07 \\
Variance & 1.21 & 6.10 & 8.00 \\
$\mathrm{P}(\mathrm{T} \leq \mathrm{t})$ one-tail & 0.02 & 0.05 & 0.04 \\
$\mathrm{t}$ Critical one-tail & 2.13 & 2.13 & 2.13 \\
$\mathrm{P}(\mathrm{T} \leq \mathrm{t})$ two-tail & 0.04 & 0.10 & 0.09 \\
t Critical two-tail & 2.78 & No $(p>0.78)$ & 2.78 \\
Statistically significant difference? & Yes $(p<0.05)$ & & No $(p>0.05)$ \\
\hline
\end{tabular}


7 days cured

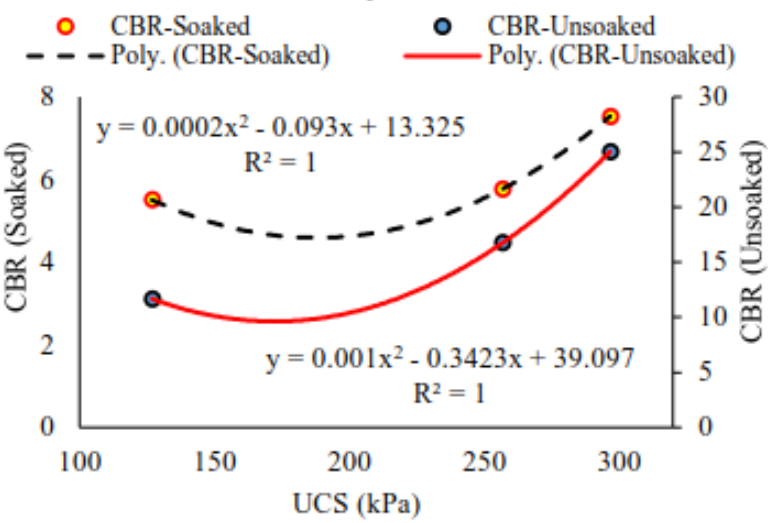

(a)

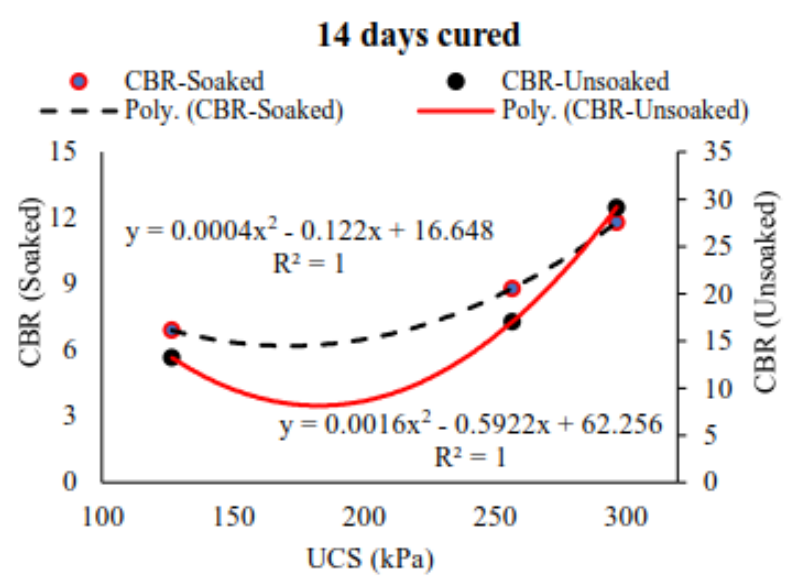

(b)

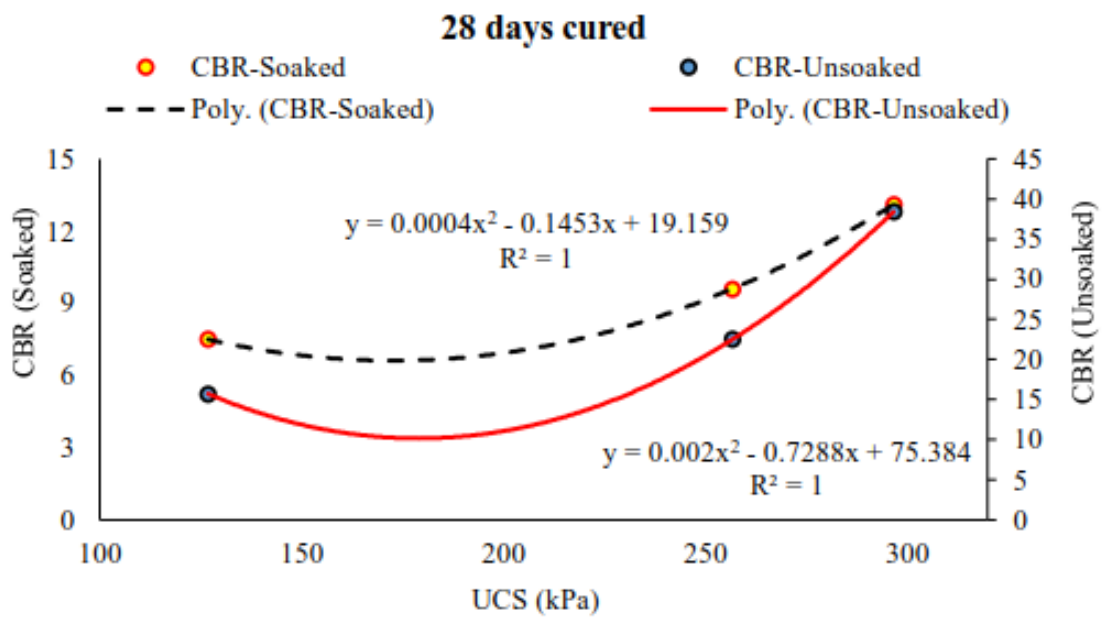

(c)

Figure 16. The statistical relationship between UCS and CBR (soaked and unsoaked) obtained after 7 (a), 14 (b), and 28 (c) days of curing.

\section{Conclusions}

This study was aimed to quantify and assess the mechanical property variations of peat resulting from the incorporation of hydraulic binders (SF and OPC) through a systematic experimental procedure. In addition to the index and compaction characteristics, the experimental program included UCS and CBR tests for mechanical property and binder effectiveness assessments. The microstructural details were obtained with SEM. The derived results were analyzed, and the following conclusions were drawn.

1. Teluk Intan peat contains high water, organic, and fiber contents; is classified as an $\mathrm{H}_{3}$ level of humification that is acidic in nature; and possesses a low UCS value of $42.94 \mathrm{kPa}$.

2. Overall, the MDD values increased and the OMC reduces with increasing amounts of $\mathrm{SF}$ and OPC due to the involvement of hydraulic reactions.

3. Similar to MDD, the mechanical properties (UCS and CBR) of the stabilized peat were enhanced with increasing amounts of binders and longer curing periods. The effectiveness of these binders was acceptable for highway subgrade improvement after 28 days of proper curing.

4. Considering the targeted SDI of 7.03, the strength development by SF more rapid than that of OPC.

5. Both the hydraulic binders (SF and OPC) and their mixes enhanced strength but induced brittle failure after increasing the binder dosage. 
6. The morphological studies revealed the hollow cavities/pores, spongy organic matter, flaky and loosely packed internal structure of the parent peat, which evolved into a compact matrix with strong interparticle bonds when using SF and OPC.

7. Effective statistical models were generated for the assessment of UCS and CBR (soaked and unsoaked) with increasing amounts of SF ranging from 10 to $20 \%$ and curing periods of 7,14 , and 28 days. Moreover, a strong correlation $\left(R^{2}>0.9\right)$ was observed between the UCS and CBR (soaked and unsoaked) of SF-stabilized peat.

Author Contributions: Conceptualization, A.A. and M.H.S.; methodology, A.A. and M.H.S.; formal analysis, A.A. and N.R.b.A.; investigation, A.A. and N.R.b.A.; writing-original draft preparation, A.A.; writing-review and editing, M.H.S. and A.A.; supervision, M.H.S. and N.R.b.A.; project administration, M.H.S., M.B. and M.E.M.; funding acquisition, M.H.S., M.B. and M.E.M. All authors have read and agreed to the published version of the manuscript.

Funding: This research and APC were funded by the "Universiti Teknologi PETRONAS-University College of Technology Sarawak", grant number "015MD0-036".

Institutional Review Board Statement: Not applicable.

Informed Consent Statement: Not applicable.

Data Availability Statement: Not applicable.

Acknowledgments: The authors are grateful to the Malaysian government, Universiti Teknologi PETRONAS, and University College of Technology Sarawak. Additionally, the assistance of OM Materials (Sarawak) Sdn Bhd in providing the silica fume is highly acknowledged. Lastly, the first author is thankful to Muhammad Safdar (UET-Peshawar) for his unending support and cooperation.

Conflicts of Interest: The authors declare no conflict of interest.

\section{References}

1. Ahmad, A.; Sutanto, M.H.; Al-Bared, M.A.M.; Harahap, I.S.H.; Abad, S.V.A.N.K.; Khan, M.A. Physio-Chemical Properties, Consolidation, and Stabilization of Tropical Peat Soil Using Traditional Soil Additives-A State of the Art Literature Review. KSCE J. Civ. Eng. 2021, 25, 3662-3678. [CrossRef]

2. Ahmad, A.; Sutanto, M.H.; Harahap, I.S.H.; Al-Bared, M.A.M.; Khan, M.A. Feasibility of Demolished Concrete and Scraped Tires in Peat Stabilization-A Review on the Sustainable approach in Stabilization. In Proceedings of the 2020 Second International Sustainability and Resilience Conference: Technology and Innovation in Building Designs, Sakheer, Bahrain, 11-12 November 2020; pp. 1-5.

3. Muhammad, N.; Siddiqua, S. Full factorial design for optimization of magnesium alkalinization additive. Transp. Geotech. 2019, 21, 100294. [CrossRef]

4. Vincevica-Gaile, Z.; Teppand, T.; Kriipsalu, M.; Krievans, M.; Jani, Y.; Klavins, M.; Setyobudi, R.H.; Grinfelde, I.; Rudovica, V.; Tamm, T.; et al. Towards Sustainable Soil Stabilization in Peatlands: Secondary Raw Materials as an Alternative. Sustainability 2021, 13, 6726. [CrossRef]

5. Mahmood, A.A.; Hussain, M.K.; Mohamad, S.N.A. Use of palm oil fuel ash (POFA)-stabilized Sarawak peat composite for road subbase. Mater. Today Proc. 2020, 20, 505-511. [CrossRef]

6. Panesar, D.K. Supplementary Cementing Materials; Elsevier: Amsterdam, The Netherlands, 2019; pp. 55-85. [CrossRef]

7. Kalantari, B.; Prasad, A.; Huat, B.B.K. Cement and Silica Fume Treated Columns to Improve Peat Ground. Arab. J. Sci. Eng. 2012, 38, 805-816. [CrossRef]

8. Kalantari, B.; Prasad, A.; Huat, B.B.K. Stabilising peat soil with cement and silica fume. Proc. Inst. Civ. Eng. Geotech. Eng. 2011, 164, 33-39. [CrossRef]

9. Rikmann, E.; Zekker, I.; Teppand, T.; Pallav, V.; Shanskiy, M.; Mäeorg, U.; Tenno, T.; Burlakovs, J.; Liiv, J. Relationship between Phase Composition and Mechanical Properties of Peat Soils Stabilized Using Oil Shale Ash and Pozzolanic Additive. Water 2021, 13, 942. [CrossRef]

10. Wong, L.S.; Hashim, R.; Ali, F. Improved strength and reduced permeability of stabilized peat: Focus on application of kaolin as a pozzolanic additive. Constr. Build. Mater. 2013, 40, 783-792. [CrossRef]

11. Hebib, S.; Farrell, E.R. Some experiences on the stabilization of Irish peats. Can. Geotech. J. 2003, 40, 107-120. [CrossRef]

12. Sariosseiri, F.; Muhunthan, B. Effect of cement treatment on geotechnical properties of some Washington State soils. Eng. Geol. 2009, 104, 119-125. [CrossRef]

13. ASTM International. ASTM-D2166/D2166M-16, Standard Test. Method for Unconfined Compressive Strength of Cohesive Soil; ASTM International: West Conshohocken, PA, USA, 2016.

14. Kaniraj, S.R.; Gayathri, V. Factors Influencing the Strength of Cement Fly Ash Base Courses. J. Transp. Eng. 2003, 129, 538-548. [CrossRef] 
15. ASTM International. ASTM-D1883-16, Standard Test. Method for CBR (California Bearing Ratio) of Laboratory-Compacted Soils; ASTM International: West Conshohocken, PA, USA, 2016. Available online: http:/ /www.astm.org/Standards/D4429.htm (accessed on 10 March 2021).

16. ASTM International. ASTM-D698-12, Standard Test. Methods for Laboratory Compaction Characteristics of Soil Using Standard Effort (12 $400 \mathrm{ft}$-lbf/ft3 (600 kN-m/m3)); ASTM International: West Conshohocken, PA, USA, 2021.

17. El Mouchi, A.; Siddiqua, S.; Wijewickreme, D.; Polinder, H. A Review to Develop new Correlations for Geotechnical Properties of Organic Soils. Geotech. Geol. Eng. 2021, 39, 3315-3336. [CrossRef]

18. Haut, B. Problematic Soils; Universiti Putra Malaysia Press: Serdang, Malaysia, 2004.

19. ASTM International. ASTM D4427-13, Standard Classification of Peat Samples by Laboratory Testing 1; ASTM International: West Conshohocken, PA, USA, 2013. [CrossRef]

20. ASTM International. ASTM:D2974-00, Standard Test. Methods for Moisture, Ash, and Organic Matter of Peat and Other Organic Soils; ASTM International: West Conshohocken, PA, USA, 2000.

21. Hashim, R.; Islam, S. Engineering Properties of Peat Soils in Peninsular, Malaysia. J. Appl. Sci. 2008, 8, 4215-4219. [CrossRef]

22. Youventharan, D.; Arif, S.M.; Rokiah, O. Ultimate bearing capacity of peat treated with cement columns in physical model. In Proceedings of the 3rd National Conference on Wind and Earthquake Engineering \& International Seminar on Sustainable Construction Engineering (NCWE \& ISSCE 2019), Kuala Lumpur, Malaysia, 2-13 July 2019; pp. 1-7.

23. Landva, A.O.; Pheeney, P.E. Peat fabric and structure. Can. Geotech. J. 1980, 17, 416-435. [CrossRef]

24. ASTM International. ASTM_D854-14, Standard Test. Methods for Specific Gravity of Soil Solids by Water Pycnometer; ASTM International: West Conshohocken, PA, USA, 2014. Available online: www.astm.org (accessed on 15 February 2021).

25. ASTM International. ASTM_D4318-10, Standard Test. Methods for Liquid Limit, Plastic Limit, and Plasticity Index of Soils; ASTM International: West Conshohocken, PA, USA, 2010. [CrossRef]

26. ASTM International. ASTM_D2434-19, Standard Test. Method for Permeability of Granular Soils (Constant Head); ASTM International: West Conshohocken, PA, USA, 2019. [CrossRef]

27. ASTM International. ASTM:D1997-91, Standard Test. Method for Laboratory Determination of the Fiber Content of Peat Samples by Dry Mass; ASTM International: West Conshohocken, PA, USA, 2001.

28. Cai, G.; Liu, S. Compaction and mechanical characteristics and stabilization mechanism of carbonated reactive MgO-stabilized silt. KSCE J. Civ. Eng. 2017, 21, 2641-2654. [CrossRef]

29. Paul, A.; Hussain, M. Cement Stabilization of Indian Peat: An Experimental Investigation. J. Mater. Civ. Eng. 2020, 32, 04020350. [CrossRef]

30. Rahman, Z.A.; Sulaiman, N.; Rahim, S.A.; Idris, W.M.R.; Lihan, T. Effect of cement additive and curing period on some engineering properties of treated peat soil. Sains Malaysiana 2016, 45, 1679-1687.

31. Pashaki, E.A. Geomechanical properties of peat stabilized with cement and sand. Int. J. Adv. Appl. Sci. 2017, 4, 19-25. [CrossRef]

32. Kalantari, B.; Huat, B.B.K. Peat soil stabilization, using Ordinary Portland Cement, Polypropylene fibers, and Air Curing Technique, Electron. J. Geotech. Eng. 2008, 13, 1-13. Available online: http://www.ejge.com/2008/Ppr0888.pdf (accessed on 25 March 2021).

33. Kolay, P.K.; Rahman, A. Physico-geotechnical properties of peat and its stabilisation. Proc. Inst. Civ. Eng. Ground Improv. 2016, 169, 206-216. [CrossRef]

34. Zain, N.H.M.; Zulastry, M.I. Compressive Strength of Peat Soil Treated with Waste Tyre Granules. In Proceedings of the Annual International Conference on Architecture and Civil Engineering, Singapore, 26-27 June 2019; pp. 185-192. [CrossRef]

35. Agarwal, S. Pozzolanic activity of various siliceous materials. Cem. Concr. Res. 2006, 36, 1735-1739. [CrossRef]

36. Dehghanbanadaki, A.; Arefnia, A.; Keshtkarbanaeemoghadam, A.; Ahmad, K.; Motamedi, S.; Hashim, R. Evaluating the compression index of fibrous peat treated with different binders. Bull. Int. Assoc. Eng. Geol. 2017, 76, 575-586. [CrossRef]

37. Sing, W.L.; Hashim, R.; Ali, F.H. Behavior of Stabilized Peat Soils in Unconfined Compression Tests. Am. J. Eng. Appl. Sci. 2008, 1, 274-279. [CrossRef]

38. Axelsson, K.; Johansson, S.; Andersson, R. 3rd Report: Stabilization of Organic Soils by Cement and Puzzolanic ReactionsFeasibility Study, Linkoping (Sweden). 2002. Available online: www.swedgeo.se/sd/pdf/SD-R3E.pdf (accessed on 20 March 2021).

39. Kalantari, B.; Prasad, A.; Huat, B.B. Peat stabilization using cement, polypropylene and steel fibres. Géoméch. Eng. 2010, 2, 321-335. [CrossRef]

40. Bhurtel, A.; Eisazadeh, A. Strength and Durability of Bottom Ash and Lime Stabilized Bangkok Clay. KSCE J. Civ. Eng. 2019, 24, 404-411. [CrossRef]

41. Yang, Y.; Wang, G.; Xie, S.; Tu, X.; Huang, X. Effect of mechanical property of cemented soil under the different pH value. Appl. Clay Sci. 2013, 79, 19-24. [CrossRef]

42. Zhang, L.; O'Kelly, B.C.; Nagel, T.; Vandamme, M.; Dangla, P.; Pereira, J.-M.; Ghabezloo, S. Tensile and Compressive Contributions of Fibres in Peat; American Society of Civil Engineers (ASCE): Reston, VA, USA, 2017; pp. 1466-1473.

43. Tiwari, N.; Satyam, N.; Shukla, S.K. An experimental study on micro-structural and geotechnical characteristics of expansive clay mixed with EPS granules. Soils Found. 2020, 60, 705-713. [CrossRef]

44. Wahab, N.; Roshan, M.; Rashid, A.; Hezmi, M.; Jusoh, S.; Norsyahariati, N.N.; Tamassoki, S. Strength and Durability of Cement-Treated Lateritic Soil. Sustainability 2021, 13, 6430. [CrossRef] 
45. Chenarboni, H.A.; Lajevardi, S.H.; MolaAbasi, H.; Zeighami, E. The effect of zeolite and cement stabilization on the mechanical behavior of expansive soils. Constr. Build. Mater. 2021, 272, 121630. [CrossRef]

46. Amadi, A.; Sadiku, S.; Abdullahi, M.; Danyaya, H. Case study of construction quality control monitoring and strength evaluation of a lateritic pavement using the dynamic cone penetrometer. Int. J. Pavement Res. Technol. 2018, 11, 530-539. [CrossRef]

47. Schaefer, V.R.; White, D.J.; Ceylan, H.; Stevens, L.J. Design Guide for Improved Quality of Roadway Subgrades and Subbases, Ames, United States. 2008. Available online: http:/ /lib.dr.iastate.edu/intrans_reports/46\%0AThis (accessed on 20 March 2021).

48. Kalantari, B.; Huat, B.B.; Prasad, A. Effect of Polypropylene Fibers on the California Bearing Ratio of Air Cured Stabilized Tropical Peat Soil. Am. J. Eng. Appl. Sci. 2010, 3, 1-6. [CrossRef]

49. Muhardi, G.; Wibisono, H.; Febrie, R.Z. Peat soils stabilization using lime-cement mixture to prevent peat fires. In Proceedings of the International Conference in Advanced Civil Environmental Engineering (ICAnCEE 2018), Bali, Indonesia, 24-25 October 2018; pp. 1-8. [CrossRef]

50. Ibrahim; Herius, A.; Fikri, J.; Ramadhinata, M.S. Maryani Stabilization of Peat Soils Using Petrasoil with Cement Viewed From CBR Value and Free Compressive Strength Value Of Soils. J. Physics Conf. Ser. 2020, 1500. [CrossRef]

51. Putri, E.E.; Yuliet, R.; Harris, L.E.; Makinda, J. Stabilization of Rimbo Panjang peat soil using lightweight materials mixed with cement as subgrade for road pavement. Int. J. Geomate. 2020, 18, 30-36. [CrossRef]

52. Bui, N.K.; Satomi, T.; Takahashi, H. Influence of industrial by-products and waste paper sludge ash on properties of recycled aggregate concrete. J. Clean. Prod. 2019, 214, 403-418. [CrossRef]

53. Sudhakaran, S.P.; Sharma, A.K.; Kolathayar, S. Soil Stabilization Using Bottom Ash and Areca Fiber: Experimental Investigations and Reliability Analysis. J. Mater. Civ. Eng. 2018, 30, 04018169. [CrossRef]

54. Kolay, P.K.; Taib, S.N.L. Physical and geotechnical properties of tropical peat and its stabilization. In Bülent Topcuoğlu and Metin Turan; IntechOpen: Rijeka, Croatia, 2018; p. 13.

55. Tang, B.L.; Bakar, I.; Chan, C.M. Reutilization of organic and peat soils by deep cement mixing. Int. J. Civ. Environ. Eng. 2011, 5, 87-92. [CrossRef]

56. Islam, M.S.; Hashim, R. Behaviour of stabilised peat: A field study. Sci. Res. Essays. 2010, 5, 2366-2374.

57. Sapar, N.I.F.; Matlan, S.J.; Mohamad, H.M.; Alias, R. A study on physical and morphological characteristics of tropical peat in sabah. Int. J. Adv. Res. Eng. Technol. 2020, 11, 542-553. [CrossRef]

58. Amuda, A.G.; Hasan, A.; Unoi, D.N.D.; Linda, S.N. Strength and compressibility characteristics of amorphous tropical peat. J. Geoengin. 2019, 14, 85-96. [CrossRef]

59. Islam, M.S.; Hashim, R. Bearing capacity of stabilised tropical peat by deep mixing method. Aust. J. Basic Appl. Sci. 2009, 3, 682-688. Available online: http:/ /www.ajbasweb.com/ajbas/2009/682-688.pdf (accessed on 11 February 2021).

60. Ullah, Z.; Qureshi, M.I.; Ahmad, A.; Khan, S.U.; Javaid, M.F. An experimental study on the mechanical and durability properties assessment of E-waste concrete. J. Build. Eng. 2021, 38, 102177. [CrossRef]

61. Ahmad, A.; Adil, M.; Khalil, A.; Rahman, M. Mechanical properties and durability of boardcrete blocks prepared from recycled cardboard. J. Build. Eng. 2021, 33, 101644. [CrossRef]

62. Jia, L.; Guo, J.; Jiang, Y.; Fu, Y.; Zhou, Z.; Lim, S.M.; Zhao, X. Experimental Investigation on Shear Strength Parameters of Lime Stabilized Loess. Sustainability 2019, 11, 5397. [CrossRef]

63. Khan, M.I.; Sutanto, M.H.; Sunarjono, S.; Room, S.; Yusoff, N.I.M. Effect of Crumb Rubber, Epolene (EE-2), and Date Palm Ash as Modifiers on the Performance of Binders and Mixtures: A Sustainable Approach. Sustainability 2019, 11, 6484. [CrossRef]

64. Khan, M.I.; Huat, H.Y.; Dun, M.H.B.M.; Sutanto, M.H.; Jarghouyeh, E.N.; Zoorob, S.E. Effect of Irradiated and NonIrradiated Waste PET Based Cementitious Grouts on Flexural Strength of Semi-Flexible Pavement. Materials 2019, 12, 4133. [CrossRef] [PubMed]

65. Cui, Y.; Gao, K.; Zhang, P. Experimental and Statistical Study on Mechanical Characteristics of Geopolymer Concrete. Materials 2020, 13, 1651. [CrossRef] 